\title{
Effect of Breed Purity and Rearing Systems on the Stability of Sliced Iberian Dry-Cured Ham Stored in Modified Atmosphere and Vacuum Packaging
}

\author{
Rosario Ramírez (D), Rebeca Contador (D), Alberto Ortiz (D), Susana García-Torres (D), María Montaña López-Parra (D) \\ and David Tejerina *
}

Citation: Ramírez, R.; Contador, R.; Ortiz, A.; García-Torres, S.;

López-Parra, M.M.; Tejerina, D. Effect of Breed Purity and Rearing Systems on the Stability of Sliced Iberian Dry-Cured Ham Stored in Modified Atmosphere and Vacuum Packaging. Foods 2021, 10, 730. https://doi.org/ 10.3390 /foods 10040730

Academic Editor: Veronique S Sante-Lhoutellier

Received: 3 March 2021

Accepted: 25 March 2021

Published: 30 March 2021

Publisher's Note: MDPI stays neutral with regard to jurisdictional claims in published maps and institutional affiliations.

Copyright: (C) 2021 by the authors Licensee MDPI, Basel, Switzerland. This article is an open access article distributed under the terms and conditions of the Creative Commons Attribution (CC BY) license (https:// creativecommons.org/licenses/by/ $4.0 /)$
Meat Quality Area, Center for Scientific and Technological Research of Extremadura (CICYTEX-La Orden), Junta de Extremadura, Guadajira, 06187 Badajoz, Spain; mariarosario.ramirez@juntaex.es (R.R.); rebecontro@gmail.com (R.C.); alberto.ortiz@juntaex.es (A.O.); susana.garciat@juntaex.es (S.G.-T.); montana.lopez@juntaex.es (M.M.L.-P.)

* Correspondence: tejerinabarrado@yahoo.es; Tel.: +34-924-01-40-88

\begin{abstract}
The long-term storage stability of three quality categories of sliced Iberian dry-cured ham defined by the Spanish Iberian Quality Standard (Black, purebred Iberian reared outdoors in Montanera system; Red, Iberian $\times$ Duroc crossed (50\%) pigs reared outdoors in Montanera system; and White, Iberian $\times$ Duroc crossed (50\%) pigs commercially fed) and packaged under vacuum and modified atmosphere packaging (MAP) was studied. Commercial category affected the shelf life, being Black and Red presented the highest lipid oxidation during storage, whereas the effect of packaging was not as clear as the effect of commercial category. MAP preserved more the colour and the antioxidants content than vacuum packaging, while this latter reduced lipid oxidation development and maintained better the brightness and flavour of slices than MAP.
\end{abstract}

Keywords: pre-packaged sliced Iberian dry-cured ham; commercial categories; pig breed; Montanera; shelf life; sensory evaluation

\section{Introduction}

Iberian dry-cured products are highly appreciated not only by Spanish consumers [1], among whom they represent a relevant part in their diet, but also in the European market [2]. Iberian pigs have been traditionally reared outdoors in Mediterranean evergreen forests with feeding based on acorns mainly from Quercus rotundifolia and grass, namely the Montanera system [3], which results in the top quality Iberian products. Due to the growing demand for Iberian products, the Iberian sector has further diversified, including crossbreeding with Duroc breed [4] and the use of concentrate fed during the last fattening phase of the traditional Montanera system. Many research studies evaluated the impact of these production systems on the final product from a quality viewpoint, reporting the impact of the genetic background on fatty acid profile and sensory attributes [5] as well as on the physico-chemical characteristics and oxidative stability [6] of Iberian dry-cured ham. On the other hand, the feeding background of pigs affects the intramuscular fat, fatty acid and tocopherol profile of dry-cured hams [2,7]. This variety in the productive systems give rise to different quality standards in the final product, which are compiled in the current Spanish Iberian Quality Standard (IQS) [8] that regulates the Iberian breed purity and the rearing system, among other factors. This regulation classifies Iberian dry-cured products into four quality categories, which are commercially labelled with different colours: "Black" (100\% Iberian pigs finished in Montanera), "Red" (a minimum of 50\% Iberian pigs finished in Montanera), "Green" (a minimum of 50\% Iberian pigs in outdoor system and fed with commercial fed and/or acorns and grass) and "White" (a minimum of 50\% Iberian pigs in indoor systems and commercial fed). This could influence the technological aptitude of 
Iberian dry-cured hams. Consequently, it is important to know the effect of the commercial category in the shelf life of the sliced and packaged products.

The importance of new commercial formats of Iberian dry-cured ham has increased in recent years $[1,9]$. The traditional selling format as the whole piece implies that consumers should buy $5-7 \mathrm{~kg}$ of this product at once. This fact, together its high price, makes it difficult to purchase and consume, thus pre-packaged sliced Iberian dry-cured hamespecially vacuum and modified atmosphere packaging (MAP) [10] — has become popular. Specifically, for the Iberian dry-cured ham market, the selling format tends towards MAP format, since the product presentation is more similar to the original hand-sliced dry-cured ham and it reduces the slice adherence of the vacuum-packaging [10-12].

Although new selling formats provide more consumption flexibility and selling potential, the shelf life could decrease, since oxidative processes and alterations in colour and other nutrients are enhanced when the product is presented in sliced form, especially in MAP, as concluded Parra et al. [12]. In addition, Iberian dry-cured ham could present different shelf life according to its commercial category since the feeding background affects the antioxidants in the muscle [3]. Previous studies in dry-cured loin and chorizo have shown the importance of the commercial category of Iberian dry-cured meat products and the packaging conditions for the shelf life of the sliced product during storage [13,14].

Therefore, the aim of this research was to evaluate the differences in the main quality characteristics of pre-packaged sliced Iberian dry-cured hams from three commercial categories defined by the IQS. In parallel, we studied the shelf life of each commercial category and characterised the effect of the type of packaging — vacuum and MAP-through long-term refrigerated storage and retail display conditions.

\section{Material and Methods}

\subsection{Material}

\subsubsection{Iberian Dry-Cured Hams}

Iberian dry-cured hams with three different commercial categories (Black, Red and White) defined by the IQS [8] were studied. According to these guidelines, pigs from Black and Red categories were reared under free-range system in dehesa ecosystem, during $70-80$ days, with a replacement of 50-60 kg from the ad libitum intake of acorns and grass. In both, the age at slaughter was 15-16 months. The main differences between them were the Iberian breed purity (100\% Iberian vs. $50 \%$ Iberian $\times$ Duroc) and the carcass weight (110-115 kg vs. 120-122 kg) for Black and Red category, respectively. Animals from White category $(50 \%$ Iberian $\times$ Duroc) were reared under semi-intensive conditions, with a minimum total free floor area of $2 \mathrm{~m}^{2}$ /animal during last fattening phase (70-80 days) and commercial feeding. The age at slaughter was 11-12 months with the carcass weight of $115-118 \mathrm{~kg}$.

Raw hams were initially salted, and then progressively dried following the IQS [8] in a local facility, with $9.6 \pm 0.6,10.1 \pm 0.4$ and $10.6 \pm 0.7 \mathrm{~kg}$ of ham weight and 42,42 and 30 months of maturation for Black, Red and White, respectively.

\subsubsection{Experimental Design}

In total, 18 Iberian dry-cured hams from the three categories were used: Black $(n=6)$, Red $(\mathrm{n}=6)$ and White $(\mathrm{n}=6)$. Hams were hand-sliced at $1.5-3 \mathrm{~mm}$ thickness and homogeneously distributed in $100 \mathrm{~g}$ package formats.

Packaging of hams was carried out in a local facility. In total, 720 packages were evaluated (480 and 240 for physico-chemical and sensory analysis, respectively), 120 packages of each quality commercial category which were divided homogeneously to obtain the following groups: (i) vacuum-packaged sliced ( $\mathrm{n}=120$ (80 and 40 for physico-chemical and sensory analysis, respectively)); and (ii) MAP ( $\mathrm{n}=120$ (80 and 40 for physico-chemical and sensory analysis, respectively)). Packages of the three commercial qualities in both packaging conditions (vacuum packaging and MAP) were stored in refrigerated conditions $\left(4{ }^{\circ} \mathrm{C}\right)$ for 12 months and studied every 4 months of storage: T0 (initial, $\mathrm{n}=40(20+20)$ ), 
T4 (4 months of storage, $\mathrm{n}=20(20+0))$, T8 $(8$ months of storage $\mathrm{n}=40(20+20))$ and T12 $(12$ months of storage, $\mathrm{n}=20(20+0))$.

\subsubsection{Packaging}

Slices of dry-cured ham were vacuum-packaged using a laminated film (oxygen permeability, $9.3 \mathrm{~cm}^{3} \mathrm{O}_{2} / \mathrm{m}^{2} / 24 \mathrm{~h}$ at $4{ }^{\circ} \mathrm{C}$ ), using an EGARVAC ${ }^{\circledR}$ packaging unit. MAP was carried out in a commercial mixture of gases with the proportion $70 \% \mathrm{~N}_{2}-30 \% \mathrm{CO}_{2}$ in an Ulma ${ }^{\circledR}$ SMART 300 packaging equipment (Gipuzkoa, Spain), using polystyrene trays (150 mm thick) with an oxygen permeability of $3.2 \mathrm{~cm}^{3} / \mathrm{m}^{2} / 24 \mathrm{~h}$ at $4{ }^{\circ} \mathrm{C}$ and sealed with $70 \mathrm{~mm}$ thick polyethylene film (VIDUCA, Alicante, Spain) with an oxygen permeability of $1 \mathrm{~cm}^{3} / \mathrm{m}^{2} / 24 \mathrm{~h}\left(23{ }^{\circ} \mathrm{C} ; 50 \% \mathrm{RH}\right), 5.5 \mathrm{~cm}^{3} / \mathrm{m}^{2} / 24 \mathrm{~h}\left(23{ }^{\circ} \mathrm{C} ; \mathrm{RH}\right)$ to $\mathrm{CO}_{2}$ and $2.2 \mathrm{~g} / \mathrm{m}^{2} / 24 \mathrm{~h}$ $\left(25{ }^{\circ} \mathrm{C} ; 90 \% \mathrm{RH}\right)$ to $\mathrm{H}_{2} \mathrm{O}$.

\subsubsection{Storage}

All packages were stored at $+4{ }^{\circ} \mathrm{C}$ under darkness for 12 months except in the last $72 \mathrm{~h}$ before their analysis, which occurred under fluorescent white light (616 LUX, $60 \mathrm{~W}$ ) to reproduce commercial conditions. Packages are normally stored in darkness by the ham companies that slice the hams, and only when the packages are presented in the supermarket are they under illumination. For physico-chemical analysis, the sample unit was the packaging, so these were opened after the time of storage and the total content of each tray was homogenised, with an IKA homogeniser, except for the instrumental colour (which was measured on the intact slices) for subsequent analysis.

\subsection{Methods}

\subsubsection{Moisture and Chloride Content}

Moisture was tested following the AOAC method [15] and chloride content $(\mathrm{NaCl})$ using the Volhard method [16]. The results were expressed in $\mathrm{g} / 100 \mathrm{~g}^{-1}$ of dry-cured ham as mean values.

Initial levels of fat content of packages were analysed and quantified gravimetrically with chloroform/methanol $(2: 1, v / v)$, following the method of Folch, Lees and SloaneStanley [17]. In total, 18 packages per commercial category were analysed. Total fat content of packages of hams of category were $18.0 \pm 6.0$ (Black), $17.4 \pm 4.4$ (Red) and $16.0 \pm 6.0$ (White) $\mathrm{g} 100^{-1}$. Those high levels of fat correspond to the sum of subcutaneous, intramuscular and intermuscular fat content. All these types of fat are present in each ham slice.

\subsubsection{Instrumental Colour Measurement}

The parameters obtained in the CIE Lab space were lightness $\left(\mathrm{L}^{*}\right)$, redness $\left(\mathrm{a}^{*}\right.$, which evaluates the range of red to green) and yellowness $\left(b^{*}\right.$, which evaluates the range of yellow to blue) using a Minolta CR-400 colourimeter (Minolta Camera, Osaka, Japan) with illuminant D65, a $0^{\circ}$ standard observer and a $2.5 \mathrm{~cm}$ port/viewing area. The equipment was standardised before developing the measurements with a white tile. Additionally, the saturation index or chroma $\left(\mathrm{C}^{*}\right)$, defined as $\mathrm{C}=\left(\mathrm{a}^{2}+\mathrm{b}^{2}\right)^{0.5}$, and hue angle $\left(\mathrm{H}^{\circ}\right)$, as arctangent $b^{*} / a^{*}$, were calculated. The measurements were repeated at five randomly chosen places on each package and averaged.

\subsubsection{Tocopherols Composition}

Tocopherols ( $\alpha$ and $\gamma$ ) were quantified following the method described by Cayuela, Garrido, Sancho Bañón and Ros [18]. Extraction was carried out by saponifying solution $\left(\mathrm{KOH} 11.5 \%\right.$ in $\left.\mathrm{EtOH} / \mathrm{H}_{2} \mathrm{O} 55: 45\right)$. Tocopherol analysis was performed on an Agilent Technologies HPLC Series 1100 instrument (Agilent Technologies, Santa Clara, CA, USA), with a Kromasil Silica column $(5 \mu \mathrm{m}$ particle size, $150 \times 4.6 \mathrm{~cm})($ Symta, Madrid, Spain) and a Kromasil Silica Guard Column (10 $\mu \mathrm{m})$ (Symta, Madrid, Spain). The mobile phase was hexane:isopropanol:etanol $(98.5: 1: 0.5 \mathrm{v} / \mathrm{v} / \mathrm{v})$, at a flow rate of $1 \mathrm{~mL} / \mathrm{min}$, and the 
fluorescence detector (Agilent Technologies Series 1200) was fixed at $\lambda$-excitation of $295 \mathrm{~nm}$ and $\lambda$-emission of $330 \mathrm{~nm}$. Identification and quantification of the tocopherol compounds were made by comparison with standards analysed in similar conditions $(0.2-14 \mu \mathrm{g} / \mathrm{mL})$. The results were expressed as $\mu \mathrm{g} \mathrm{g}^{-1}$.

\subsubsection{Lipid Oxidation}

Lipid oxidation was evaluated by the 2-thiobarbituric acid (TBA) method of Salih, Smith, Price and Dawson [19]. TBARS values were determined from the standard (1,1,1,3tetraethoxypropane, TEP) curve and expressed as mg malondialdehyde (MDA) $\mathrm{kg}^{-1}$.

\subsubsection{Protein Oxidation}

Protein oxidation was evaluated following the method described by Oliver, Ahn, Moerman, Goldstein and Satadtman [20]. The formation of carbonyl groups during incubation with 2,4-dinitrophenylhydrazine (DNPH) in $2 \mathrm{~N} \mathrm{HCl}$ was analysed. Carbonyls levels were determined by measuring DNPH incorporated on the basis of absorption of $21.0 \mathrm{mM}^{-1} \mathrm{~cm}^{-1}$ at $370 \mathrm{~nm}$ for protein hydrazones. The results were expressed as nmol of DNPH fixed per $\mathrm{mg}$ of protein. Protein concentration was calculated by spectrophotometry at $280 \mathrm{~nm}$ using bovine serum albumin (BSA) as standard. Protein oxidation was expressed as nmol carbonyls mg protein ${ }^{-1}$.

\subsubsection{Fatty Acids Profile}

The fatty acids composition was analysed in the fat previously extracted following the method of Folch et al. [17]. From this, $210 \mu \mathrm{L}$ were taken and mixed with $4 \mathrm{~mL}$ of hexane and $200 \mu \mathrm{L}$ of $\mathrm{KOH}(85 \%$ in $\mathrm{MetOH})$. It was mixed and centrifuged (at $3000 \mathrm{rpm}$ for $10 \mathrm{~min}$ ), and, then, the organic phase was collected in vials. One microlitre was injected into a gas chromatograph equipped (model 4890 Series II; Hewlett-Packard, Palo Alto, CA, USA) with a split/split-less injector and a flame ionisation detector. A Carbowax ${ }^{\mathrm{TM}}$ fused silica capillary column $(30 \mathrm{~m} \times 0.25 \mathrm{~mm}$ id; $0.25 \mu \mathrm{m}$ film thickness; Ohio Valley, Marietta, OH, USA) was used for the separation of FAMEs. The carrier gas was nitrogen at $1.8 \mathrm{~mL} \mathrm{~min}^{-1}$. The oven temperature was held at $200^{\circ} \mathrm{C}$. The injector and detector were set at $250{ }^{\circ} \mathrm{C}$. The identification of individual FAME was based on a standard mixture of 37 Component FAME Mix (Sigma-Aldrich, Supelco 37 Component FAME Mix- CRM47885, St. Louis, MO, USA). Results were expressed as percentage of FAMEs in dry-cured ham sample, as mean values.

\subsubsection{Sensory Analysis}

Prior to sensory analysis, microbiological analysis was carried out to confirm the microbial safety of slices before testing. To ensure microbial safety, total mesophiles, coliforms, E. coli, Clostridium perfringens and Staphylococcus aureus counts, as well as presence/absence of Listeria monocytogenes and Salmonella sp., were carried out on 5 random packages before sensorial analysis. Microbiological counts determined that the samples at the time of sensory analysis were suitable for consumption. Eight trained panellists evaluated nine sensory parameters of Iberian dry-cured ham slices. From each package, two slices were provided to each panellist as a representative as possible sample, being of sufficient size, similar intramuscular and subcutaneous fat and without visual defects. Sensory analysis was carried out at the beginning (T0) and after 8 months of refrigerated storage (T8). The visual appearance was assessed by means of two parameters: brightness (from little bright to intense) and marbling (level of visible intramuscular fat: from very lean to very marbled). The intensity of the typical flavour of dry-cured ham was also evaluated (from odourless to intense odour). The texture perceived while chewing was assessed according to hardness (from very tender to very firm) and juiciness (from not juicy to very juicy). Other parameters evaluated were the intensity of tastes (from tasteless to tasteful) such as salty, rancidity, unpleasant or strange tastes and the persistency of the typical flavour of dry-cured ham in mouth (from not perceptible to very persistent). In each session, samples 
of vacuum and MAP from the three commercial categories were evaluated. Samples were randomly presented to panellists. All sessions were conducted at ambient temperature in a sensory room equipped with white fluorescent lighting. Panellists evaluated the different parameters by means of a quantitative-descriptive analysis on a scale from 0 to 10. Water (approximately $100 \mathrm{~mL}$ ) at room temperature was provided to the panellists between samples.

\subsubsection{Statistical Analysis}

A multivariate analysis of variance (Two-way ANOVA) was applied to data obtained using the software SPSS.PC + v.20.0, taking into account the commercial category (Black, Red and White) and the type of packaging (vacuum vs. MAP) effects, and their interaction. One-way ANOVA test was also applied to analyse the effect of the storage at the beginning (T0), 4 months (T4), 8 months (T8) and 12 months (T12). In the sensory analysis, one-way ANOVA was applied to evaluate the effect of the storage (T0 and T8). Mean and standard error of mean (SEM) are reported. SEM include data of the commercial category and the type of packaging. Tukey's HSD test was applied to compare the mean values of each group. Statistical significance was set at $p \leq 0.05$. In addition, a principal component analysis was carried out using Unscrambler $\mathrm{X}\left(\mathrm{CAMO}^{\circledR}\right.$ Trondheim, Norway) to check the overall effect of the commercial categories (Black, Red and White) and refrigerated storage time (T0, T4, T8 and T12) in each type of packaging (A (vacuum); and B (MAP)) (Figure 1) and the effect of packaging in each commercial category (Figure 2) ((A) Black; (B) Red; and (C) White) and to explore the multivariate relationships among variables.

A.- Vacuum

A.1. Sampling grouping by commercial category
B.- MAP

B.1. Sampling grouping by commercial category
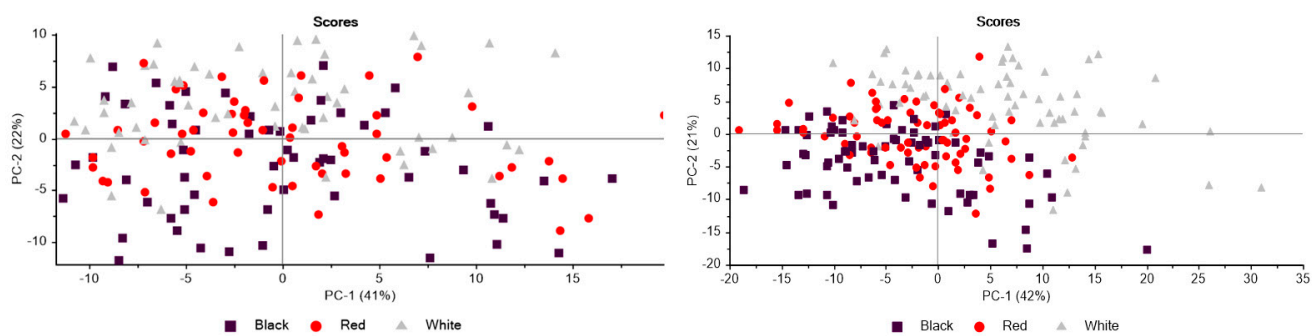

- Black - Red 4 White

A.2. Sampling grouping by storage time

B.2. Sampling grouping by storage time
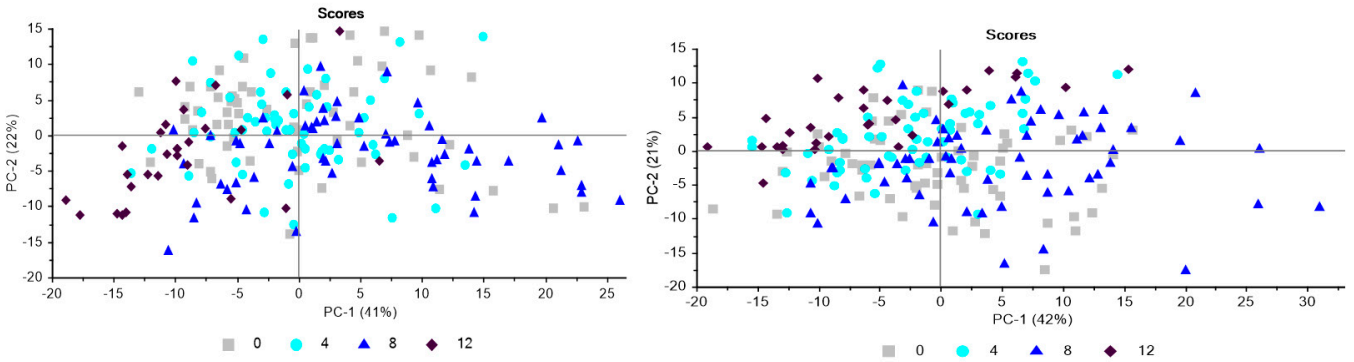

Figure 1. Principal component analyses (PCA) of Iberian dry-cured ham from three commercial categories (Black, Red and White) and different refrigerated $\left(4^{\circ} \mathrm{C}\right)$ storage time (T0, T4, T8 and T12) packed under: vacuum (A); and modified atmosphere (MAP) $\left(70 \% \mathrm{O}_{2}: 30 \% \mathrm{CO}_{2}\right)$. (A). PCA for vacuum packaging, using $\alpha$ - and $\gamma$-tocopherols, (-) C16:0, (-) C18:0 and C18:1 n-9 (PC1) and L*, C18:2 n-6 and C18:3 n-3 (PC2). (B). PCA of MAP, using (-) $\alpha$ and (-) $\gamma$-tocopherols, C16:0, C18:0 and (-) C18:1 n-9 (PC1) and (-) C18:2 n-6 and (-) C18:3 n-3 (PC2). Sampling grouping by commercial category is shown in (A.1,B.1): Black, Red and White are presented as black, red and grey markers, respectively. It is shown by storage time in (A.2,B.2): T0, T4, T8 and T12 are presented as grey, light blue, dark blue and black markers, respectively. 

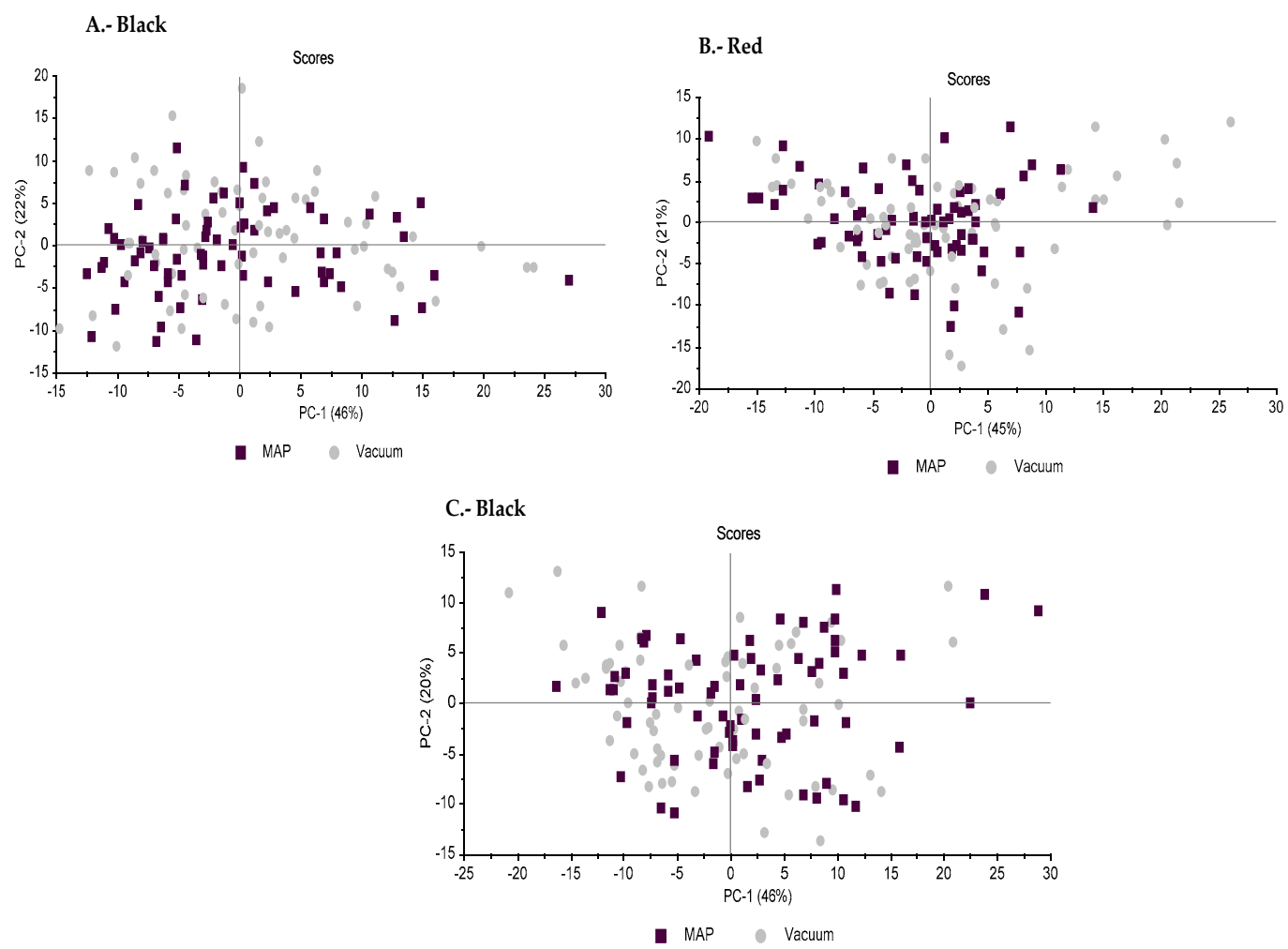

Figure 2. Principal component analyses (PCA) of Iberian dry-cured ham from two packaging format (vacuum and MAP) of three commercial categories: Black (A); Red (B); and White (C). Sampling grouping by type of packaging: Vacuum (grey markers) and MAP (black markers). (A) PCA of Black category, using (-) C16:0, (-) C18:0, C18:1 n-9 and C18:2 n-6 (PC1) and $\mathrm{a}^{*}$, Chroma, (-) lipid oxidation and (-) C18:3 n-3 (PC2). (B) PCA of Red category, using (-) L*, C16:0, C18:0 and (-) C18:1 n-9 (PC1) and (-) lipid oxidation, C18:2 n-6 and C18:3 n-3 (PC2). (C) PCA of White category, using C16:0, (-) C16:1, C18:0 and (-) C18:1 n-9 (PC1) and $L^{*}, b^{*}$, Hue and C18:2 n-6 (PC2).

\section{Results and Discussion}

Moisture and salt content of sliced dry-cured ham (Table 1) showed important changes due to the commercial category, while the type of packaging slightly influenced the parameters evaluated. Significant interactions between the commercial category and the type of packaging were found in moisture content at $\mathrm{T} 8$ and $\mathrm{NaCl}$ at $\mathrm{T} 4$. These are difficult to explain since they only appeared at specific times of storage.

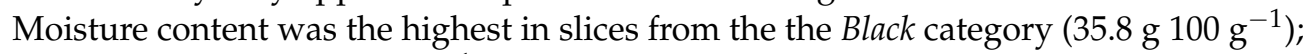

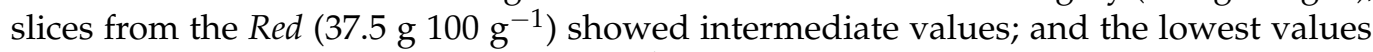

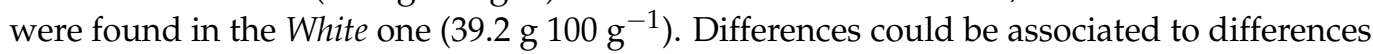
in the ripening times (42 months in Black and Red vs. 30 months in White categories) or inter- and intramuscular fat content. In general, the ripening time of these top-quality hams is quite long, and, in some cases, it could take several (3-5) years, which allows a slow moisture loss and the slow development typical maturation changes.

Regarding the effect of the type of packaging, after 12 months of storage (T12), slices in MAP showed significantly higher dry-matter content than vacuum-packaging, probably explained by the higher loss of moisture in the former. In fact, Parra et al. [10] found higher moisture content in slices of Iberian dry-cured ham packaged in vacuum in comparison with MAP after 60 days of storage. Iberian ham producers usually recommend the consumption of sliced hams after no longer than 6-8 months, principally due to the loss of sensory quality of the sliced ham, but there are no studies to support this. 
Table 1. Moisture content (g $100 \mathrm{~g}^{-1}$ of ham) and $\mathrm{NaCl}$ (g $100 \mathrm{~g}^{-1}$ of ham) of sliced Iberian dry-cured ham from different commercial categories and with different packaging conditions for 12 months of refrigeration storage.

\begin{tabular}{|c|c|c|c|c|c|c|c|c|c|c|}
\hline & & \multicolumn{3}{|c|}{ Commercial Category (1) } & \multicolumn{2}{|c|}{ Packaging (2) } & \multirow{2}{*}{ SEM } & \multicolumn{3}{|c|}{$p$ Value } \\
\hline & & Black & Red & White & MAP & Vacuum & & 1 & 2 & $1 \times 2$ \\
\hline$N$ total $*$ & & 80 & 80 & 80 & 120 & 120 & & & & \\
\hline \multirow{6}{*}{ Moisture } & T0 & $35.8 \mathrm{a}$ & $37.5 \mathrm{~b}$ & $39.2 \mathrm{c}$ & 37.5 & 37.5 & 0.29 & 0.001 & 0.967 & 0.587 \\
\hline & $\mathrm{T} 4$ & $35.9 \mathrm{a}$ & $38.3 \mathrm{~b}$ & $39.8 \mathrm{c}$ & 37.5 & 38.5 & 0.29 & 0.001 & 0.065 & 0.191 \\
\hline & $\mathrm{T} 8$ & $34.8 \mathrm{a}$ & $38.0 \mathrm{~b}$ & $39.6 \mathrm{c}$ & 37.5 & 37.5 & 0.31 & 0.001 & 0.923 & 0.019 \\
\hline & $\mathrm{T} 12$ & $35.7 \mathrm{a}$ & $38.3 \mathrm{~b}$ & $39.6 \mathrm{c}$ & 36.6 & 39.1 & 0.43 & 0.001 & 0.001 & 0.704 \\
\hline & SEM & 0.22 & 0.24 & 0.27 & 0.21 & 0.25 & & & & \\
\hline & $p$ value & 0.180 & 0.565 & 0.901 & 0.465 & 0.066 & & & & \\
\hline \multirow{6}{*}{$\mathrm{NaCl}$} & T0 & $4.1 \mathrm{c}$ & $4.2 \mathrm{~b}$ & $4.3 \mathrm{a}$ & 4.2 & 4.2 & 0.04 & 0.060 & 0.512 & 0.377 \\
\hline & $\mathrm{T} 4$ & $4.1 \mathrm{~b}$ & $4.3 \mathrm{a}$ & $4.2 \mathrm{ab}$ & 4.3 & 4.2 & 0.03 & 0.007 & 0.149 & 0.007 \\
\hline & $\mathrm{T} 8$ & $4.1 \mathrm{~b}$ & $4.3 \mathrm{a}$ & $4.3 \mathrm{a}$ & 4.2 & 4.2 & 0.04 & 0.003 & 0.708 & 0.144 \\
\hline & $\mathrm{T} 12$ & $4.1 \mathrm{~b}$ & $4.3 \mathrm{a}$ & $4.3 \mathrm{a}$ & 4.2 & 4.2 & 0.05 & 0.009 & 0.889 & 0.872 \\
\hline & SEM & 0.03 & 0.03 & 0.04 & 0.02 & 0.03 & & & & \\
\hline & $p$ value & 0.956 & 0.600 & 0.711 & 0.946 & 0.861 & & & & \\
\hline
\end{tabular}

SEM, standard error of mean; Values with the same letters (a-c) indicate homogeneous subsets according to $p \leq 0.05, p \leq 0.01, p \leq 0.001$. a-c: Different letters in the same row indicate significant differences in the commercial category for $p=0.05$ according to Tukey's HSD test. Black (100\% Iberian pigs finished in Montanera); Red (50\% Iberian $\times$ Duroc pigs finished in Montanera); White ( $50 \%$ Iberian $\times$ Duroc pigs reared in a semi-intensive system with commercially feeding). Modified atmosphere packaging (MAP) $\left(70 \% \mathrm{~N}_{2}: 30 \% \mathrm{CO}_{2}\right)$. Vacuum packaging. T0, initial; T4, 4 months of storage; T8, 8 months of storage; T12, 12 months of storage. * $\mathrm{N}$ total, number of determinations performed for each commercial category and for each type of packaging.

Salt content values were within the range expected for this type of product [7], and their levels were similar in all categories at the beginning of storage (ANOVA did not detect differences), although Tukey test found the highest values in White, followed by Red category and the lowest values in Black category. During the storage, values of the slices from Black category were lower than those from the Red and White ones $(p<0.01)$, possibly associated to differences in the composition of the hams. The highest values of fat on slices were found in the Black category (18.0 \pm 6.0 (Black), $17.4 \pm 4.4$ (Red), $16.0 \pm 6.0$ (White) g $100^{-1}$ sample), although differences were not significant $(p>0.05)$, which could have limited the salt penetration into the ham during salting process [21]. An interaction effect between both factors, commercial category and packaging, was observed at T4.

In general, instrumental colour showed important changes especially due to the commercial category, while the type of packaging slightly influenced the colour stability during storage (Table 2).

Table 2. Instrumental colour changes of sliced Iberian dry-cured ham from different commercial categories and with different packaging conditions for 12 months of refrigeration storage.

\begin{tabular}{|c|c|c|c|c|c|c|c|c|c|c|}
\hline & & \multicolumn{3}{|c|}{ Commercial Category (1) } & \multicolumn{2}{|c|}{ Packaging (2) } & \multirow{2}{*}{ SEM } & \multicolumn{3}{|c|}{$p$ Value } \\
\hline & & Black & Red & White & MAP & Vacuum & & 1 & 2 & $1 \times 2$ \\
\hline N total * & & 80 & 80 & 80 & 120 & 120 & & & & \\
\hline \multirow{6}{*}{$\mathbf{L}^{*}$} & T0 & $39.9 \mathrm{~b}$ & $\begin{array}{c}41.8 \\
\mathrm{abAB}\end{array}$ & $43.9 \mathrm{aA}$ & $42.4 \mathrm{~A}$ & $41.3 \mathrm{~A}$ & 0.52 & 0.004 & 0.262 & 0.252 \\
\hline & $\mathrm{T} 4$ & $39.4 \mathrm{~b}$ & $39.4 \mathrm{abB}$ & $43.7 \mathrm{aA}$ & $41.2 \mathrm{~A}$ & $40.5 \mathrm{~A}$ & 0.33 & 0.173 & 0.057 & 0.286 \\
\hline & $\mathrm{T} 8$ & $39.9 c$ & $43.3 \mathrm{bA}$ & $44.3 \mathrm{aA}$ & $43.9 \mathrm{~A}$ & $42.5 \mathrm{~A}$ & 0.56 & 0.001 & 0.150 & 0.006 \\
\hline & $\mathrm{T} 12$ & $37.1 \mathrm{~b}$ & $37.2 \mathrm{bC}$ & $40.4 \mathrm{aB}$ & $39.1 \mathrm{~B}$ & $37.3 \mathrm{~B}$ & 0.58 & 0.018 & 0.098 & 0.062 \\
\hline & SEM & 0.42 & 0.40 & 0.50 & 0.37 & 0.37 & & & & \\
\hline & $p$ value & 0.162 & 0.001 & 0.001 & 0.001 & 0.001 & & & & \\
\hline
\end{tabular}


Table 2. Cont.

\begin{tabular}{|c|c|c|c|c|c|c|c|c|c|c|}
\hline & & \multicolumn{3}{|c|}{ Commercial Category (1) } & \multicolumn{2}{|c|}{ Packaging (2) } & \multirow{2}{*}{ SEM } & \multicolumn{3}{|c|}{$p$ Value } \\
\hline & & Black & Red & White & MAP & Vacuum & & 1 & 2 & $1 \times 2$ \\
\hline N total * & & 80 & 80 & 80 & 120 & 120 & & & & \\
\hline \multirow{6}{*}{$\mathbf{a}^{*}$} & T0 & $22.4 \mathrm{~A}$ & $22.9 \mathrm{~A}$ & $23.1 \mathrm{AB}$ & $22.1 \mathrm{~A}$ & $23.5 \mathrm{~A}$ & 0.38 & 0.747 & 0.058 & 0.368 \\
\hline & $\mathrm{T} 4$ & $20.8 \mathrm{bA}$ & $23.4 \mathrm{aA}$ & $24.1 \mathrm{aA}$ & $23.2 \mathrm{~A}$ & $22.3 \mathrm{~A}$ & 0.26 & 0.001 & 0.041 & 0.619 \\
\hline & T8 & $18.4 \mathrm{bB}$ & $19.5 \mathrm{abB}$ & $20.8 \mathrm{aC}$ & $19.8 \mathrm{~B}$ & $19.4 \mathrm{~B}$ & 0.32 & 0.008 & 0.514 & 0.111 \\
\hline & $\mathrm{T} 12$ & $19.1 \mathrm{bB}$ & $20.1 \mathrm{aB}$ & $21.1 \mathrm{aC}$ & $20.8 \mathrm{~B}$ & $20.5 \mathrm{~B}$ & 0.40 & 0.005 & 0.128 & 0.546 \\
\hline & SEM & 0.34 & 0.30 & 0.30 & 0.24 & 0.28 & & & & \\
\hline & $p$ value & 0.001 & 0.001 & 0.001 & 0.001 & 0.001 & & & & \\
\hline \multirow{6}{*}{$\mathbf{b}^{*}$} & $\mathrm{T0}$ & $13.1 \mathrm{bA}$ & $14.1 \mathrm{abA}$ & $15.1 \mathrm{aA}$ & $13.6 \mathrm{~A}$ & $14.6 \mathrm{~A}$ & 0.27 & 0.011 & 0.077 & 0.409 \\
\hline & $\mathrm{T} 4$ & $12.6 \mathrm{bA}$ & $13.6 \mathrm{abA}$ & $14.7 \mathrm{aA}$ & $13.3 \mathrm{~A}$ & $14.0 \mathrm{~A}$ & 0.25 & 0.002 & 0.133 & 0.962 \\
\hline & T8 & $12.1 \mathrm{cA}$ & $13.8 \mathrm{bA}$ & $15.3 \mathrm{aA}$ & $13.7 \mathrm{~A}$ & $13.8 \mathrm{~A}$ & 0.26 & 0.001 & 0.802 & 0.077 \\
\hline & $\mathrm{T} 12$ & $9.3 \mathrm{bB}$ & $10.5 \mathrm{abB}$ & $12.6 \mathrm{aB}$ & 11.7 B & $10.0 \mathrm{~B}$ & 0.49 & 0.015 & 0.068 & 0.530 \\
\hline & SEM & 0.23 & 0.25 & 0.28 & 0.21 & 0.23 & & & & \\
\hline & $p$ value & 0.001 & 0.001 & 0.019 & 0.015 & 0.001 & & & & \\
\hline \multirow{6}{*}{ Chroma } & T0 & $26.1 \mathrm{~A}$ & $27.0 \mathrm{~A}$ & $27.7 \mathrm{AB}$ & $26.0 \mathrm{~A}$ & $27.8 \mathrm{~A}$ & 0.43 & 0.302 & 0.033 & 0.376 \\
\hline & $\mathrm{T} 4$ & $24.3 \mathrm{bAB}$ & $27.1 \mathrm{aA}$ & $28.6 \mathrm{aA}$ & $26.8 \mathrm{~A}$ & $26.6 \mathrm{AB}$ & 0.33 & 0.001 & 0.732 & 0.678 \\
\hline & $\mathrm{T} 8$ & $22.2 \mathrm{bB}$ & $24.1 \mathrm{aB}$ & $25.7 \mathrm{aB}$ & $24.1 \mathrm{~B}$ & $23.9 \mathrm{C}$ & 0.34 & 0.001 & 0.805 & 0.180 \\
\hline & $\mathrm{T} 12$ & $23.7 \mathrm{bAB}$ & $26.3 \mathrm{abA}$ & $28.4 \mathrm{aA}$ & $27.6 \mathrm{~A}$ & $24.7 \mathrm{BC}$ & 0.54 & 0.001 & 0.004 & 0.815 \\
\hline & SEM & 0.35 & 0.33 & 0.34 & 0.27 & 0.32 & & & & \\
\hline & $p$ value & 0.001 & 0.002 & 0.008 & 0.001 & 0.001 & & & & \\
\hline \multirow{6}{*}{ Hue } & T0 & $30.7 \mathrm{~A}$ & $31.8 \mathrm{~B}$ & $33.2 \mathrm{~B}$ & $31.7 \mathrm{~B}$ & $32.0 \mathrm{~B}$ & 0.46 & 0.102 & 0.751 & 0.526 \\
\hline & $\mathrm{T} 4$ & $31.2 \mathrm{~A}$ & $29.6 \mathrm{~B}$ & $31.2 \mathrm{~B}$ & 29.3 B & $32.1 \mathrm{~B}$ & 0.42 & 0.177 & 0.001 & 0.749 \\
\hline & T8 & $33.6 \mathrm{~A}$ & $35.1 \mathrm{bA}$ & $37.0 \mathrm{~A}$ & $34.8 \mathrm{~A}$ & $35.7 \mathrm{~A}$ & 0.60 & 0.058 & 0.471 & 0.019 \\
\hline & $\mathrm{T} 12$ & $23.2 \mathrm{~B}$ & $22.9 \mathrm{C}$ & $25.9 \mathrm{C}$ & $24.5 \mathrm{C}$ & $23.5 \mathrm{C}$ & 0.69 & 0.150 & 0.423 & 0.212 \\
\hline & SEM & 0.53 & 0.54 & 0.56 & 0.53 & 0.46 & & & & \\
\hline & $p$ value & 0.001 & 0.001 & 0.001 & 0.001 & 0.001 & & & & \\
\hline
\end{tabular}

SEM, standard error of mean; Values with the same letters (a-c or A-C) indicate homogeneous subsets according to commercial category and refrigerated storage time (T0, T4, T8 or T12) for $p=0.05$ according to Tukey's HSD test. Black (100\% Iberian pigs finished in Montanera); Red $(50 \%$ Iberian $\times$ Duroc pigs finished in Montanera); White $(50 \%$ Iberian $\times$ Duroc pigs reared in a semi-intensive system with commercially feeding). Modified atmosphere packaging (MAP) $\left(70 \% \mathrm{~N}_{2}: 30 \% \mathrm{CO}_{2}\right)$. Vacuum packaging. T0, initial; $\mathrm{T} 4,4 \mathrm{months}$ of storage; $\mathrm{T} 8,8 \mathrm{months}$ of storage; T12, 12 months of storage. ${ }^{*} \mathrm{~N}$ total, number of determinations performed for each commercial category and for each type of packaging.

Lightness $\left(\mathrm{L}^{*}\right)$ was mainly affected by the commercial category of ham but not by packaging. Significant interactions between commercial category and the type of packaging were found for $\mathrm{L}^{*}$ at T8. Slices from the White category showed higher lightness than those from the Black one, with those from the Red category showing intermediate values. This pattern was maintained throughout the whole storage (T0-T12) and could result from the differences in meat composition (Table 1 ).

After 12 months of storage, $\mathrm{L}^{*}$ decreased with regard of commercial category and packaging, although differences did not become significant for slices from the Black category. Reductions of lightness at the end of storage were less intense in slices from the Black category than from the others $(\Delta \mathrm{T} 12-\mathrm{T} 0:$ Black $=2.8 ;$ Red $=4.6$; White $=3.6)$. In addition, reductions of lightness were less intense in MAP than in vacuum packaging $(\Delta \mathrm{T} 12-\mathrm{T} 0)$. In contrast, Parra et al. [10] did not find influence of packaging on lightness, although they reported a decrease of this parameter during storage due to illumination. Changes of lightness in the sliced dry-cured ham could be negative since modifications in the typical colour of dry-cured ham could influence consumers' choice in the supermarket [22]. Therefore, the lower reduction of CIE L* in Black category is positive to preserve their original quality.

Redness ( $\left.\mathrm{a}^{*}\right)$ at T0 was similar in all groups; however, at longer times of storage (T4-T12), it was significantly affected by the commercial category. Redness was higher in slices from the White and Red categories than from the Black one. Differences could be associated to differences in the ham composition and/or to the longer maturation times of 
hams from Black category. After storage, important reductions of a* were found with regard of the commercial categories, being higher in slices from the Black one $(\Delta \mathrm{T} 12-\mathrm{T} 0$ : Black $=3.3$; Red $=2.8$; White $=1.9$ ). Long storage of dry-cured products can favour oxidation of the red pigments such as nytrosilmyoglobin to form metmyoglobin, leading to a progressive discolouration [23]. The decrease in red colour intensity could be negative for hams in the Black and Red categories as consumers prefer dry-cured hams with an intense red colour. Regarding to the effect of packaging, at T4, slices in vacuum packaging showed lower values of $\mathrm{a}^{*}$ than those in MAP. In addition, at the end of storage, the reductions of $\mathrm{a}^{*}$ were higher in vacuum packaging than in $\mathrm{MAP}(\triangle \mathrm{T} 12-\mathrm{T} 0$ : $\mathrm{MAP}=1.3$; Vacuum $=3.0)$, thus expressing the relevance of the packaging characteristics and especially on the permeability to oxygen on the stability of the red colour of ham [24].

Changes in the red colour of dry-cured ham are normally attributed to the oxidation of nitrosylmyoglobin [23], since this molecule is unstable in the presence of oxygen [25]. Thus, when nitrosylmyoglobin is oxidised, the metmyoglobin is formed and redness turns to a brownish colour [23].

Yellowness $\left(b^{*}\right)$ was affected by the commercial category but not by packaging, leading to higher values in slices in White than those in Black category, while the Red ones presented intermediate values. During storage, $b^{*}$ decreased in all commercial categories and packaging. Decreases of yellowness are difficult to explain since normally the bibliography associates the increases of $b^{*}$ in sliced Iberian ham to increases of lipid oxidation during storage [10]. However, in line with our results, Amaro-Blanco, Delgado-Adámez and Ramírez [26] also found reductions of $b^{*}$ in sliced Iberian dry-cured shoulder (with similar characteristics to Black category) throughout storage time, although differences were not significant due to the shorter time of storage (five months).

Chroma and hue showed changes due to the modifications of the previous colour parameters. At T4-T12, chroma was significantly higher in slices from the Red and White categories than from the Black one. Chroma was initially higher in vacuum-packaged slices than in MAP at T0, while, at the end of storage (T12), it showed the opposite behaviour. Finally, hue angle was importantly reduced during storage in all commercial categories and packaging. A significative interaction at $\mathrm{T} 8$ was observed for the latter between commercial category and packaging.

Instrumental colour was affected by the commercial category of hams, which involves the genotype and feeding/production conditions. In general, the effect of both feeding and rearing on muscle colour of the dry-cured ham is complex, since colour parameters are influenced by different factors such as the oxidation intensity, the meat composition (moisture, fat and heme pigment content) and nitrite concentration [25-27]. However, the literature describes specific changes in some colour parameters. $L^{*}$ values were lower in dry-cured Iberian hams from animals reared outdoor (Black and Red categories), which was also observed by Isabel Cordero, López-Bote and Daza [28].

Despite the fact that shelf life of Iberian dry-cured ham is relatively long (6-8 months), research studies concerning the evolution of colour attributes of either vacuum packing or MAP deal with the effect of mid-term storage, approximately 2-4 months [10-12]. Only Cilla, Matínez, Beltrán and Roncalés [29] evaluated dry-cured ham quality and acceptability under vacuum or MAP during eight months, but not from Iberian pigs and with a different gas mixture in MAP to the mixture used in the present study. In line with our results, Parra et al. [12] and Parra et al. [10] reported a great stability in the lean colour in Iberian dry-cured ham slices in MAP at similar conditions as in the current study $\left(70 \% \mathrm{~N}_{2}-30 \% \mathrm{CO}_{2}\right)$ for up to 120 days of storage. In that latter study, they also compared both types of packaging (vacuum vs. MAP), reporting that vacuum-packaging preserved colour of sliced Iberian dry-cured ham better than MAP for 60 days of storage. AmaroBlanco et al. [26] reported that the instrumental colour of slices Iberian dry-cured shoulder remained unchanged after 150 days of storage using vacuum packaging.

The antioxidants contents (Table 3 ) of the slices of Iberian dry-cured ham were importantly influenced by the commercial category, which in turn is affected by the genotype 
and the diet. $\alpha$-tocopherol content was significantly higher at all sampling times (T0-T12) in slices from the Black category than from the White one, while the Red category showed intermediate levels. Regarding packaging, MAP showed higher levels of $\alpha$-tocopherol at T0, T4 and T12. $\gamma$-Tocopherol was significantly higher in slices from the Black and Red categories than those from the White one at all times of storage (T0-T12). However, levels were importantly reduced during storage in slices from the Black category. In addition, at T0, $\gamma$-tocopherol content was higher in MAP than in vacuum packages.

Table 3. Tocopherol content $\left(\mu \mathrm{g} \mathrm{g}^{-1}\right.$ ) and lipid (TBARS values) and protein oxidation changes of sliced Iberian dry-cured ham from different commercial categories and with different packaging conditions for 12 months of refrigeration storage.

\begin{tabular}{|c|c|c|c|c|c|c|c|c|c|c|}
\hline & & \multicolumn{3}{|c|}{ Commercial Category (1) } & \multicolumn{2}{|c|}{ Packaging (2) } & \multirow{2}{*}{ SEM } & \multicolumn{3}{|c|}{$p$ Value } \\
\hline & & Black & Red & White & MAP & Vacuum & & 1 & 2 & $1 \times 2$ \\
\hline N total * & & 80 & 80 & 80 & 120 & 120 & & & & \\
\hline \multirow{6}{*}{$\alpha$-Tocopherol } & T0 & $11.2 \mathrm{a}$ & $8.7 \mathrm{~b}$ & $4.0 \mathrm{c}$ & 8.8 & 7.1 & 0.37 & 0.001 & 0.001 & 0.060 \\
\hline & $\mathrm{T} 4$ & $10.5 \mathrm{a}$ & $7.9 \mathrm{~b}$ & $4.0 \mathrm{c}$ & 7.8 & 7.1 & 0.31 & 0.001 & 0.049 & 0.338 \\
\hline & $\mathrm{T} 8$ & $10.5 \mathrm{a}$ & $8.0 \mathrm{~b}$ & $4.0 \mathrm{c}$ & 7.8 & 7.2 & 0.31 & 0.001 & 0.111 & 0.510 \\
\hline & $\mathrm{T} 12$ & $9.9 \mathrm{a}$ & $8.1 \mathrm{~b}$ & $3.7 \mathrm{c}$ & 7.7 & 6.8 & 0.39 & 0.001 & 0.008 & 0.502 \\
\hline & SEM & 0.266 & 0.168 & 0.062 & 0.266 & 0.215 & & & & \\
\hline & $p$ value & 0.477 & 0.359 & 0.473 & 0.426 & 0.833 & & & & \\
\hline \multirow{6}{*}{$\gamma$-Tocopherol } & T0 & $1.1 \mathrm{aA}$ & $1.1 \mathrm{a}$ & $0.3 \mathrm{~b}$ & 0.9 & 0.7 & 0.04 & 0.001 & 0.008 & 0.224 \\
\hline & $\mathrm{T} 4$ & $1.0 \mathrm{aAB}$ & $1.0 \mathrm{a}$ & $0.3 \mathrm{~b}$ & 0.7 & 0.7 & 0.05 & 0.001 & 0.837 & 0.990 \\
\hline & $\mathrm{T} 8$ & $1.0 \mathrm{aAB}$ & $1.0 \mathrm{a}$ & $0.3 \mathrm{~b}$ & 0.8 & 0.7 & 0.04 & 0.001 & 0.905 & 0.996 \\
\hline & T12 & $0.8 \mathrm{aB}$ & $1.0 \mathrm{a}$ & $0.3 \mathrm{~b}$ & 0.7 & 0.7 & 0.05 & 0.001 & 0.787 & 0.981 \\
\hline & SEM & 0.03 & 0.03 & 0.01 & 0.03 & 0.03 & & & & \\
\hline & $p$ value & 0.035 & 0.724 & 0.744 & 0.279 & 0.836 & & & & \\
\hline \multirow{6}{*}{ mg MDA kg ${ }^{-1}$} & T0 & $1.9 \mathrm{aC}$ & $1.7 \mathrm{abC}$ & $1.6 \mathrm{bC}$ & $1.8 \mathrm{D}$ & $1.7 \mathrm{C}$ & 0.04 & 0.001 & 0.119 & 0.001 \\
\hline & $\mathrm{T} 4$ & $2.1 \mathrm{aC}$ & $1.8 \mathrm{abC}$ & $1.7 \mathrm{bBC}$ & $1.9 \mathrm{C}$ & $1.8 \mathrm{C}$ & 0.03 & 0.001 & 0.003 & 0.543 \\
\hline & $\mathrm{T} 8$ & $2.3 \mathrm{aB}$ & $2.1 \mathrm{abB}$ & $1.8 \mathrm{bB}$ & $2.2 \mathrm{~B}$ & $2.0 \mathrm{~B}$ & 0.03 & 0.001 & 0.001 & 0.001 \\
\hline & T12 & $2.5 \mathrm{aA}$ & $2.5 \mathrm{aA}$ & $2.1 \mathrm{bA}$ & $2.5 \mathrm{~A}$ & $2.2 \mathrm{~A}$ & 0.06 & 0.005 & 0.024 & 0.964 \\
\hline & SEM & 0.03 & 0.04 & 0.03 & 0.03 & 0.03 & & & & \\
\hline & $p$ value & 0.001 & 0.001 & 0.001 & 0.001 & 0.001 & & & & \\
\hline \multirow{6}{*}{$\begin{array}{l}\text { nmol carbonyls } \\
\text { mg }^{-1} \text { protein }\end{array}$} & T0 & $4.2 \mathrm{aB}$ & $3.7 \mathrm{bB}$ & $3.5 \mathrm{bB}$ & $3.8 \mathrm{~B}$ & $3.7 \mathrm{~B}$ & 0.04 & 0.001 & 0.119 & 0.227 \\
\hline & $\mathrm{T} 4$ & $4.2 \mathrm{aB}$ & $3.7 \mathrm{bB}$ & $3.5 \mathrm{bB}$ & $3.8 \mathrm{~B}$ & $3.8 \mathrm{~B}$ & 0.04 & 0.001 & 0.793 & 0.128 \\
\hline & $\mathrm{T} 8$ & $4.5 \mathrm{aA}$ & $3.8 \mathrm{bAB}$ & $3.8 \mathrm{bA}$ & $4.0 \mathrm{AB}$ & $4.1 \mathrm{~A}$ & 0.05 & 0.001 & 0.324 & 0.019 \\
\hline & T12 & $4.5 \mathrm{aA}$ & $4.0 \mathrm{bA}$ & $3.9 \mathrm{bA}$ & $4.2 \mathrm{~A}$ & $4.1 \mathrm{~A}$ & 0.06 & 0.001 & 0.536 & 0.929 \\
\hline & SEM & 0.04 & 0.03 & 0.03 & 0.03 & 0.03 & & & & \\
\hline & $p$ value & 0.001 & 0.029 & 0.001 & 0.002 & 0.001 & & & & \\
\hline
\end{tabular}

SEM, standard error of mean; Values with the same letters (a-c or A-C) indicate homogeneous subsets according to commercial category and re-frigerated storage time (T0, T4, T8 or T12) for $p=0.05$ according to Tukey's HSD test. Black (100\% Iberian pigs finished in Montanera); Red ( $50 \%$ Iberian $\times$ Duroc pigs finished in Montanera); White $(50 \%$ Iberian $\times$ Duroc pigs reared in a semi-intensive system with commercially feeding). Modified atmosphere packaging (MAP) $\left(70 \% \mathrm{~N}_{2}: 30 \% \mathrm{CO}_{2}\right)$. Vacuum packaging. T0, initial; T4, $4 \mathrm{months}$ of storage; T8, $8 \mathrm{months}$ of storage; T12, 12 months of storage. ${ }^{*} \mathrm{~N}$ total, number of determinations performed for each commercial category and for each type of packaging.

Differences in the antioxidant content due to commercial categories could be explained by the differences of feeding background of pigs, with acorns and grass increasing the content of antioxidants in muscle. More specifically, the $\alpha$-tocopherol content in muscles from pigs reared in the Montanera system is associated with the richness in $\alpha$-tocopherol of the grass, whereas $\gamma$-tocopherol is linked to the acorns [3]. Differences found in $\alpha$ tocopherol between slices from the Black and Red categories may be associated to differences in $\alpha$-tocopherol content in the grass that pigs consumed, as reported by Tejerina, GarcíaTorres, Cabeza de Vaca, Vázquez and Cava [30]. The antioxidant content of meat has technological implications in its stability, since tocopherols ( $\alpha$ - and $\gamma$-isomers) levels present in the muscle affect the susceptibility to lipid oxidation of different tissues in vivo, in vitro and post-mortem [31]. 
Lipid oxidation development (Table 3) was higher in slices from hams of the Black category than those from the White category, while those from Red category had intermediate values of TBARS throughout the whole storage period. These differences are unexpected since the bibliography has reported a higher oxidative stability of Iberian hams from pigs reared outdoors [3,7]. Probably the longer maturation time of hams from the Black than the White category could explain these differences since lipid oxidation increases along maturation [32]. In addition, at T4-T12, the type of packaging also affected the TBARS values, which were higher in MAP than in vacuum packages. Significant interactions between commercial category and the type of packaging were found at T0 and T8. These could indicate that the lipid oxidative pattern of the commercial categories were different in each type of packaging (vacuum vs. MAP). TBARS values increased in all groups during storage, but they were more marked at T8 and T12. The increase between the beginning and the end of storage, were similar in all categories but slightly higher in the Red one ( $\Delta \mathrm{T} 12-\mathrm{T} 0$ : Black $=0.6 ; \operatorname{Red}=0.8 ;$ White $=0.5$ ). The type of packaging caused a similar increase in the TBARS values after 12 months of storage $(\triangle \mathrm{T} 12-\mathrm{T} 0$ : $\mathrm{MAP}=0.7$; Vacuum $=0.6)$. Other authors have also reported an increase in TBARS values in Iberian sliced dry-cured ham in MAP and vacuum packaging during storage $[10,12]$. In fact, plastic envelopes in packages have some permeability to oxygen. Increases of TBARS were also reported by AmaroBlanco et al. [26] during long storage of sliced Iberian dry-cured shoulder in vacuum packaging. The progressive increase of lipid oxidation during long times of storage could be caused by some oxygen permeability of packages and by illumination, which allows the development of oxidative reactions. Regarding the benefits of MAP or vacuum packaging for sliced Iberian dry-cured hams, Parra et al. $[10,12]$ concluded that the preservation of lipid oxidative stability was best achieved using vacuum packaging rather than MAP (70\% $\mathrm{N}_{2}-30 \% \mathrm{CO}_{2}$ ). Slices in MAP were also perceived as more rancid than vacuum packaged slices. Differences between those studies and ours would be caused by differences in the oxygen permeability, the illumination of slices and the differences in the characteristics of Iberian hams used to carry out the studies (i.e., rearing systems of pigs).

Similarly, to the trend showed for lipid oxidation, protein oxidation was significantly higher in hams from the Black category than those from the Red and White ones. In this case, the type of packaging utilised did not affect the increase of protein oxidation. Significant interactions between commercial category and the type of packaging were found at $\mathrm{T} 8$, in line with results of TBA-RS. At the end of storage, all groups increased protein oxidation, especially at T8 and T12. Generally, lipid and protein oxidation follow the same trend since both are affected by unsaturated fatty acids, pigments, transition metals and other compounds [33]. Cava, Ladero, González, Carrasco and Ramírez [34] reported that lipid and protein oxidation levels increased after 90 days of storage in vacuum sliced dry-cured ham from pigs fed with concentrate. However, Amaro-Blanco et al. [26] found that TBARS values increased in sliced Iberian dry-cured shoulder in vacuum-packaging from pigs reared in the Montanera system, whereas no increases in protein oxidation were found after 150 days of storage. Our results suggest that lipid oxidation reactions could be initiated before the protein oxidation reactions, which are observed after long times of storage, especially after eight months.

The fatty acids profile (Table 4) was significantly affected by the commercial category, and, as a result, it was affected by the breed and/or the diet. Slices from the White category had significantly highest percentages of total saturated fatty acids (SFA) such as palmitic and stearic acids. In contrast, hams from the Black and Red categories presented the highest percentages of total monounsaturated fatty acids (MUFA) as well as oleic acid and polyunsaturated fatty acids such as linolenic acid. The sum of polyunsaturated fatty acids (PUFA) was the highest at initial times (T0 and T4) in the Black and the Red hams, while the lowest percentages were found in the White hams. However, at longer times of storage than T4, these differences in the sum of PUFA did not appear. Interactions between factors of analysis (commercial category vs. type of packaging) were significant at $\mathrm{T} 0$ for some fatty acids such as C18:0 and C18:3 n-3; and, during storage, such as C16:1 (T8 and T12) and 
C18:1 n-9 (T4, T8 and T12). Interactions at T0 are difficult to explain; however, interactions during storage could be caused by differences in the lipolytic effect of enzymes in slices from each category due to the type of packaging, which could cause changes in the fatty acids' percentage during storage.

Table 4. Fatty acids profile (per cent of FAMEs) changes of sliced Iberian dry-cured ham from different commercial categories and with different packaging conditions for 12 months of refrigeration storage.

\begin{tabular}{|c|c|c|c|c|c|c|c|c|c|c|}
\hline & & \multicolumn{3}{|c|}{ Commercial Category (1) } & \multicolumn{2}{|c|}{ Packaging (2) } & \multirow{2}{*}{ SEM } & \multicolumn{3}{|c|}{$p$ Value } \\
\hline & & Black & Red & White & MAP & Vacuum & & 1 & 2 & $1 \times 2$ \\
\hline N total * & & 80 & 80 & 80 & 120 & 120 & & & & \\
\hline \multirow{6}{*}{ C16:0 } & T0 & $22.0 \mathrm{bB}$ & $22.1 \mathrm{bB}$ & $23.9 \mathrm{aB}$ & $22.7 \mathrm{~B}$ & $22.7 \mathrm{~B}$ & 0.11 & 0.001 & 0.623 & 0.105 \\
\hline & $\mathrm{T} 4$ & $22.4 \mathrm{bB}$ & $21.9 \mathrm{cB}$ & $24.0 \mathrm{aB}$ & $22.5 \mathrm{~B}$ & $23.0 \mathrm{~B}$ & 0.12 & 0.001 & 0.075 & 0.108 \\
\hline & T8 & $22.2 \mathrm{bB}$ & $22.0 \mathrm{bB}$ & $23.3 \mathrm{aC}$ & $22.4 \mathrm{~B}$ & $22.6 \mathrm{~B}$ & 0.14 & 0.001 & 0.361 & 0.209 \\
\hline & $\mathrm{T} 12$ & $23.5 \mathrm{bA}$ & $22.9 \mathrm{cA}$ & $24.6 \mathrm{aA}$ & $23.4 \mathrm{~A}$ & $23.9 \mathrm{~A}$ & 0.14 & 0.001 & 0.087 & 0.150 \\
\hline & SEM & 0.12 & 0.08 & 0.08 & 0.09 & 0.10 & & & & \\
\hline & $p$ value & 0.005 & 0.002 & 0.001 & 0.007 & 0.001 & & & & \\
\hline \multirow{6}{*}{ C16:1 } & T0 & $2.9 \mathrm{bAB}$ & $3.0 \mathrm{bA}$ & $3.7 \mathrm{aA}$ & $3.3 \mathrm{~A}$ & $3.1 \mathrm{AB}$ & 0.05 & 0.001 & 0.064 & 0.158 \\
\hline & $\mathrm{T} 4$ & $3.0 \mathrm{bA}$ & $3.0 \mathrm{bA}$ & $3.8 \mathrm{aA}$ & $3.4 \mathrm{~A}$ & $3.2 \mathrm{~A}$ & 0.04 & 0.001 & 0.091 & 0.204 \\
\hline & $\mathrm{T} 8$ & $3.0 \mathrm{bA}$ & $3.0 \mathrm{bA}$ & $3.7 \mathrm{aA}$ & $3.2 \mathrm{~A}$ & $3.3 \mathrm{~A}$ & 0.05 & 0.001 & 0.654 & 0.002 \\
\hline & T12 & $2.7 \mathrm{bB}$ & $2.8 \mathrm{bB}$ & $3.3 \mathrm{aB}$ & $3.0 \mathrm{~B}$ & $2.9 \mathrm{~B}$ & 0.053 & 0.001 & 0.377 & 0.039 \\
\hline & SEM & 0.03 & 0.03 & 0.04 & 0.04 & 0.03 & & & & \\
\hline & $p$ value & 0.022 & 0.067 & 0.001 & 0.011 & 0.011 & & & & \\
\hline \multirow{6}{*}{ C18:0 } & T0 & $10.1 \mathrm{bB}$ & $9.9 \mathrm{bB}$ & $10.9 \mathrm{aAB}$ & $10.3 \mathrm{~B}$ & $10.3 \mathrm{~B}$ & 0.09 & 0.001 & 0.786 & 0.012 \\
\hline & $\mathrm{T} 4$ & $10.8 \mathrm{bAB}$ & $10.4 \mathrm{bB}$ & $11.4 \mathrm{aAB}$ & $10.4 \mathrm{~B}$ & $11.3 \mathrm{~A}$ & 0.10 & 0.001 & 0.001 & 0.737 \\
\hline & $\mathrm{T} 8$ & $10.2 \mathrm{~B}$ & $10.0 \mathrm{~B}$ & $10.2 \mathrm{~B}$ & $10.1 \mathrm{~B}$ & $10.2 \mathrm{~B}$ & 0.15 & 0.738 & 0.823 & 0.088 \\
\hline & $\mathrm{T} 12$ & $11.2 \mathrm{bA}$ & $10.9 \mathrm{bA}$ & $11.9 \mathrm{aA}$ & $11.1 \mathrm{~A}$ & $11.6 \mathrm{~A}$ & 0.11 & 0.001 & 0.082 & 0.916 \\
\hline & SEM & 0.12 & 0.09 & 0.11 & 0.08 & 0.10 & & & & \\
\hline & $p$ value & 0.014 & 0.001 & 0.001 & 0.001 & 0.001 & & & & \\
\hline \multirow{6}{*}{ C18:1 n-9 } & T0 & $53.3 \mathrm{aA}$ & $53.8 \mathrm{a}$ & $50.5 \mathrm{~b}$ & $52.6 \mathrm{~B}$ & $\begin{array}{l}52.5 \\
\mathrm{AB}\end{array}$ & 0.20 & 0.001 & 0.925 & 0.054 \\
\hline & $\mathrm{T} 4$ & $53.4 \mathrm{aA}$ & $53.8 \mathrm{a}$ & $50.7 \mathrm{~b}$ & $53.2 \mathrm{~A}$ & $52.0 \mathrm{~B}$ & 0.22 & 0.001 & 0.001 & 0.939 \\
\hline & T8 & $53.4 \mathrm{aA}$ & $53.1 \mathrm{a}$ & $50.7 \mathrm{~b}$ & $53.3 \mathrm{~A}$ & $52.8 \mathrm{~A}$ & 0.25 & 0.001 & 0.042 & 0.104 \\
\hline & $\mathrm{T} 12$ & $52.6 \mathrm{aB}$ & $53.5 \mathrm{a}$ & $50.6 \mathrm{~b}$ & $52.8 \mathrm{~B}$ & $51.7 \mathrm{C}$ & 0.24 & 0.001 & 0.002 & 0.614 \\
\hline & SEM & 0.18 & 0.17 & 0.19 & 0.16 & 0.18 & & & & \\
\hline & $p$ value & 0.016 & 0.064 & 0.081 & 0.028 & 0.001 & & & & \\
\hline \multirow{6}{*}{ C18:2 n-6 } & T0 & $7.1 \mathrm{aA}$ & $6.6 \mathrm{ab}$ & $6.4 \mathrm{~b}$ & 6.6 & 6.8 & 0.08 & 0.001 & 0.283 & 0.497 \\
\hline & $\mathrm{T} 4$ & $6.5 \mathrm{abB}$ & $6.9 \mathrm{a}$ & $6.3 \mathrm{~b}$ & 6.6 & 6.5 & 0.08 & 0.002 & 0.484 & 0.249 \\
\hline & $\mathrm{T} 8$ & $6.7 \mathrm{AB}$ & 6.5 & 6.6 & 6.6 & 6.6 & 0.08 & 0.452 & 0.999 & 0.632 \\
\hline & $\mathrm{T} 12$ & $6.6 \mathrm{~B}$ & 6.6 & 6.3 & 6.4 & 6.6 & 0.11 & 0.322 & 0.443 & 0.691 \\
\hline & SEM & 0.08 & 0.09 & 0.05 & 0.06 & 0.07 & & & & \\
\hline & $p$ value & 0.015 & 0.240 & 0.125 & 0.673 & 0.436 & & & & \\
\hline \multirow{6}{*}{ C18:3 n-3 } & T0 & $1.1 \mathrm{aA}$ & $1.1 \mathrm{aA}$ & $0.8 \mathrm{bA}$ & $1.0 \mathrm{~A}$ & $1.0 \mathrm{~A}$ & 0.01 & 0.001 & 0.596 & 0.016 \\
\hline & $\mathrm{T} 4$ & $0.6 \mathrm{aB}$ & $0.6 \mathrm{aB}$ & $0.4 \mathrm{bB}$ & $0.5 \mathrm{~B}$ & $0.6 \mathrm{~B}$ & 0.01 & 0.001 & 0.065 & 0.062 \\
\hline & $\mathrm{T} 8$ & $0.5 \mathrm{aC}$ & $0.5 \mathrm{aC}$ & $0.3 \mathrm{bB}$ & $0.4 \mathrm{C}$ & $0.4 \mathrm{C}$ & 0.01 & 0.001 & 0.609 & 0.109 \\
\hline & $\mathrm{T} 12$ & $0.5 \mathrm{aC}$ & $0.5 \mathrm{aC}$ & $0.4 \mathrm{bB}$ & $0.4 \mathrm{C}$ & $0.5 \mathrm{C}$ & 0.017 & 0.001 & 0.278 & 0.244 \\
\hline & SEM & 0.02 & 0.02 & 0.02 & 0.02 & 0.02 & & & & \\
\hline & $p$ value & 0.001 & 0.001 & 0.001 & 0.001 & 0.001 & & & & \\
\hline \multirow{6}{*}{ SFA } & T0 & $34.2 \mathrm{bB}$ & $34.0 \mathrm{bB}$ & $36.8 \mathrm{aB}$ & $35.0 \mathrm{~B}$ & $35.0 \mathrm{C}$ & 0.18 & 0.001 & 0.897 & 0.005 \\
\hline & $\mathrm{T} 4$ & $35.1 \mathrm{bAB}$ & $34.3 \mathrm{cB}$ & $37.4 \mathrm{aAB}$ & $35.0 \mathrm{~B}$ & $36.2 \mathrm{~B}$ & 0.20 & 0.001 & 0.001 & 0.461 \\
\hline & $\mathrm{T} 8$ & $34.5 \mathrm{bB}$ & $34.2 \mathrm{bB}$ & $35.9 \mathrm{aC}$ & $34.6 \mathrm{~B}$ & $34.9 \mathrm{C}$ & 0.28 & 0.042 & 0.573 & 0.121 \\
\hline & $\mathrm{T} 12$ & $35.4 \mathrm{bA}$ & $35.3 \mathrm{bA}$ & $38.3 \mathrm{aA}$ & $36.3 \mathrm{~A}$ & $37.4 \mathrm{~A}$ & 0.23 & 0.001 & 0.004 & 0.457 \\
\hline & SEM & 0.22 & 0.15 & 0.19 & 0.16 & 0.18 & & & & \\
\hline & $p$ value & 0.005 & 0.001 & 0.001 & 0.001 & 0.001 & & & & \\
\hline
\end{tabular}


Table 4. Cont.

\begin{tabular}{|c|c|c|c|c|c|c|c|c|c|c|}
\hline & & \multicolumn{3}{|c|}{ Commercial Category (1) } & \multicolumn{2}{|c|}{ Packaging (2) } & \multirow{2}{*}{ SEM } & \multicolumn{3}{|c|}{$p$ Value } \\
\hline & & Black & Red & White & MAP & Vacuum & & 1 & 2 & $1 \times 2$ \\
\hline$N$ total * & & 80 & 80 & 80 & 120 & 120 & & & & \\
\hline \multirow{6}{*}{ MUFA } & T0 & $57.1 \mathrm{aA}$ & $57.6 \mathrm{aA}$ & $54.9 \mathrm{bA}$ & $56.7 \mathrm{~B}$ & $56.5 \mathrm{~B}$ & 0.19 & 0.001 & 0.525 & 0.023 \\
\hline & $\mathrm{T} 4$ & $57.2 \mathrm{aA}$ & $57.6 \mathrm{aA}$ & $55.4 \mathrm{bA}$ & $57.3 \mathrm{~A}$ & $56.2 \mathrm{~B}$ & 0.21 & 0.001 & 0.001 & 0.987 \\
\hline & $\mathrm{T} 8$ & $57.3 \mathrm{aA}$ & $57.2 \mathrm{aB}$ & $55.4 \mathrm{bA}$ & $57.5 \mathrm{~A}$ & $57.2 \mathrm{~A}$ & 0.26 & 0.025 & 0.442 & 0.047 \\
\hline & T12 & $56.8 \mathrm{aB}$ & $57.1 \mathrm{aB}$ & $54.4 \mathrm{bB}$ & $56.4 \mathrm{~B}$ & $55.2 \mathrm{C}$ & 0.23 & 0.001 & 0.002 & 0.726 \\
\hline & SEM & 0.19 & 0.17 & 0.21 & 0.15 & 0.18 & & & & \\
\hline & $p$ value & 0.009 & 0.001 & 0.001 & 0.001 & 0.001 & & & & \\
\hline \multirow{6}{*}{ PUFA } & T0 & $8.7 \mathrm{aA}$ & $8.4 \mathrm{bA}$ & $7.9 \mathrm{cA}$ & $8.3 \mathrm{~A}$ & $8.5 \mathrm{~A}$ & 0.09 & 0.001 & 0.266 & 0.672 \\
\hline & $\mathrm{T} 4$ & $7.7 \mathrm{abB}$ & $8.1 \mathrm{aAB}$ & $7.4 \mathrm{bB}$ & $7.8 \mathrm{~B}$ & $7.7 \mathrm{~B}$ & 0.09 & 0.001 & 0.830 & 0.200 \\
\hline & $\mathrm{T} 8$ & $7.9 \mathrm{~B}$ & $7.8 \mathrm{~B}$ & $7.8 \mathrm{AB}$ & $7.8 \mathrm{~B}$ & $7.8 \mathrm{~B}$ & 0.09 & 0.237 & 0.957 & 0.548 \\
\hline & $\mathrm{T} 12$ & $7.5 \mathrm{~B}$ & $7.7 \mathrm{~B}$ & 7.3 B & $7.4 \mathrm{~B}$ & $7.5 \mathrm{~B}$ & 0.12 & 0.144 & 0.411 & 0.652 \\
\hline & SEM & 0.09 & 0.10 & 0.06 & 0.06 & 0.07 & & & & \\
\hline & $p$ value & 0.001 & 0.010 & 0.001 & 0.001 & 0.001 & & & & \\
\hline \multirow{6}{*}{$n-6 / n-3$} & T0 & $7.2 \mathrm{bD}$ & $6.9 \mathrm{bC}$ & $8.4 \mathrm{aD}$ & $7.4 \mathrm{C}$ & $7.6 \mathrm{C}$ & 0.11 & 0.001 & 0.363 & 0.037 \\
\hline & $\mathrm{T} 4$ & $11.1 \mathrm{cC}$ & $12.6 \mathrm{bB}$ & $17.6 \mathrm{aC}$ & $15.0 \mathrm{~B}$ & $12.5 \mathrm{~B}$ & 0.32 & 0.001 & 0.001 & 0.001 \\
\hline & T8 & $14.3 \mathrm{cA}$ & $16.6 \mathrm{bA}$ & $22.3 \mathrm{aA}$ & $18.2 \mathrm{~A}$ & $17.4 \mathrm{~A}$ & 0.34 & 0.001 & 0.030 & 0.001 \\
\hline & T12 & $13.3 \mathrm{cB}$ & $15.9 \mathrm{bA}$ & $19.5 \mathrm{aB}$ & $16.4 \mathrm{AB}$ & $16.1 \mathrm{~A}$ & 0.37 & 0.001 & 0.614 & 0.047 \\
\hline & SEM & 0.23 & 0.36 & 0.46 & 0.35 & 0.30 & & & & \\
\hline & $p$ value & 0.001 & 0.001 & 0.001 & 0.001 & 0.001 & & & & \\
\hline
\end{tabular}

SEM, standard error of mean; Values with the same letters (a-c or A-D) indicate homogeneous subsets according to commercial category and re-frigerated storage time (T0, T4, T8 or T12) for $p=0.05$ according to Tukey's HSD test. Black (100\% Iberian pigs finished in Montanera); Red (50\% Iberian $\times$ Duroc pigs finished in Montanera); White $(50 \%$ Iberian $\times$ Duroc pigs reared in a semi-intensive system with commercially feeding). Modified atmosphere packaging (MAP) $\left(70 \% \mathrm{~N}_{2}: 30 \% \mathrm{CO}_{2}\right)$. Vacuum packaging. T0, initial; T4, 4 months of storage; T8, 8 months of storage; T12, 12 months of storage. PUFA, polyunsaturated fatty acids (C18:2 n-6 + C18:3 n-3 + C20:4 n-6); MUFA, monounsaturated fatty acids $(\mathrm{C} 16: 1+\mathrm{C} 17: 1+\mathrm{C} 18: 1+\mathrm{C} 20: 1) ; \mathrm{SFA}$, saturated fatty acids $(\mathrm{C} 12: 0+\mathrm{C} 14: 0+\mathrm{C} 16: 0+\mathrm{C} 17: 0+\mathrm{C} 18: 0+\mathrm{C} 20: 0) ; \mathrm{n} 6$ $=\mathrm{C} 18: 2 \mathrm{n}-6+\mathrm{C} 20: 4 \mathrm{n}-6 ; \mathrm{n} 3=\mathrm{C} 18: 3 \mathrm{n}-3 .^{*} \mathrm{~N}$ total, number of determinations performed for each commercial category and for each type of packaging.

Fatty acids profile is associated with the feed of pigs. The fatty acids profile of the dry-cured ham from the Black and Red categories is in line with that reported for free-reared pigs fed during the final fattening period in a variable expanse of land, using natural resources, grass and acorns [35]. The fatty acids profile of hams from the White category is dependent on the composition of the commercial fodder, which is accordance with that reported for hams from pigs with similar genetic [36]. Results of the fatty acids profiles agree with previous studies of Tejerina et al. [3], who evaluated the influence of the diet on the fatty acids profile of muscle of Iberian pigs reared in the Montanera system, which would correspond to the Black and Red categories, and commercial fodder, which would correspond to the White category.

Percentages of individual fatty acids and their ratios were significantly modified during storage: SFA tended to increase during storage, while MUFA and PUFA decreased. The ratio $n-6 / n-3$ was importantly increased during storage, probably due to the important reduction of n-3 fatty acids such as linolenic acid, as a result of increased oxidation, since the oxidation susceptibility is correlated exponentially with the level of unsaturation of fatty acids, hence the oxidation rate is higher in n-3 than in n-6 polyunsaturated fatty acids [37].

The fatty acids profile also affects the oxidative stability of dry-cured hams since high levels of MUFA make them more stable during the maturation process. The balanced content of antioxidants and MUFA improves the technological quality of meat [38].

Other studies have reported increases of free fatty acids during storage in sliced vacuum packaged dry-cured ham [39]. The decreases of PUFA and linoleic acid during storage could be caused by their release as free fatty acids by the action of lipolytic enzymes. The higher ratio n-6/n-3 during storage and the higher decrease of PUFA and linoleic acid in dry-cured ham from pigs commercially fed (White category) makes these more sensitive to lipid oxidation reactions. PUFA, contrary to MUFA, are very easily oxidised, leading to 
the formation of compounds that favours the development of rancidity and undesirable sensory perceptions [38].

Lipolysis is one of the main pathways for the formation of the typical characteristics of dry-cured ham since the free fatty acids from lipolytic reactions are rapidly oxidised and new aromatic compounds are formed [40]. However, the compounds formed during storage of sliced dry-cured ham would negatively affect to the original aromatic profile of Iberian dry-cured ham.

In the sensory analysis (Table 5), the brightness was significantly affected at $\mathrm{T} 8$ by the type of packaging. Slices in vacuum packaging were brighter than those in MAP, and the brightness of the ham in those packages (vacuum) was increased during storage. Brightness is a parameter related to the composition of intramuscular fat. Fat of dry-cured ham from pigs reared in the Montanera system are expected to present high brightness due to a high level of MUFA and oleic acid; however, despite the differences showed in the fatty acids profile, panellists did not appreciate differences in brightness. The reduction of the brightness in slices of ham is negative for a packaged ham, so vacuum packaging would be better than MAP at least for this parameter.

Table 5. Sensory analysis changes of sliced Iberian dry-cured ham from different commercial categories and with different packaging conditions for 12 months of refrigeration storage.

\begin{tabular}{|c|c|c|c|c|c|c|c|c|c|c|}
\hline & & \multicolumn{3}{|c|}{ Commercial Category (1) } & \multicolumn{2}{|c|}{ Packaging (2) } & \multirow{2}{*}{ SEM } & \multicolumn{3}{|c|}{$p$ Value } \\
\hline & & White & Red & Black & MAP & Vacuum & & 1 & 2 & $1 \times 2$ \\
\hline \multirow{4}{*}{ Brightness } & T0 & 5.0 & 5.1 & 5.1 & 4.9 & 5.2 & 0.101 & 0.290 & 0.656 & 0.194 \\
\hline & $\mathrm{T} 8$ & 5.2 & 5.5 & 5.8 & 5.3 & 5.8 & 0.128 & 0.123 & 0.042 & 0.637 \\
\hline & SEM & 0.137 & 0.160 & 0.120 & 0.159 & 0.224 & & & & \\
\hline & $p$ value & 0.455 & 0.147 & 0.190 & 0.163 & 0.039 & & & & \\
\hline \multirow{4}{*}{ Marbling } & T0 & $6.0 \mathrm{a}$ & $5.8 \mathrm{ab}$ & $5.1 \mathrm{~b}$ & 5.9 & 5.3 & 0.144 & 0.039 & 0.051 & 0.431 \\
\hline & $\mathrm{T} 8$ & $6.4 \mathrm{a}$ & $5.4 \mathrm{~b}$ & $5.2 \mathrm{~b}$ & 5.6 & 5.7 & 0.135 & 0.000 & 0.746 & 0.000 \\
\hline & SEM & 0.174 & 0.158 & 0.139 & 0.233 & 0.236 & & & & \\
\hline & $p$ value & 0.246 & 0.209 & 0.209 & 0.035 & 0.047 & & & & \\
\hline \multirow{4}{*}{ Flavour } & T0 & 6.4 & 6.8 & 6.5 & 6.6 & 6.5 & 0.094 & 0.299 & 0.715 & 0.758 \\
\hline & $\mathrm{T} 8$ & 5.9 & 6.0 & 6.3 & 5.9 & 6.3 & 0.091 & 0.128 & 0.050 & 0.882 \\
\hline & SEM & 0.117 & 0.109 & 0.094 & 0.180 & 0.163 & & & & \\
\hline & $p$ value & 0.030 & 0.000 & 0.048 & 0.188 & 0.163 & & & & \\
\hline \multirow{4}{*}{ Hardness } & T0 & 5.5 & 5.8 & 5.8 & 5.8 & 5.7 & 0.122 & 0.529 & 0.692 & 0.272 \\
\hline & $\mathrm{T} 8$ & 6.4 & 5.9 & 5.8 & 5.9 & 6.2 & 0.120 & 0.080 & 0.118 & 0.037 \\
\hline & SEM & 0.159 & 0.151 & 0.116 & 0.191 & 0.195 & & & & \\
\hline & $p$ value & 0.004 & 0.692 & 0.692 & 0.958 & 0.195 & & & & \\
\hline \multirow{4}{*}{ Juiciness } & T0 & 5.5 & 5.9 & 5.9 & 5.7 & 5.8 & 0.123 & 0.233 & 0.613 & 0.414 \\
\hline & $\mathrm{T} 8$ & 5.6 & 5.6 & 5.8 & 5.5 & 5.9 & 0.119 & 0.679 & 0.081 & 0.140 \\
\hline & SEM & 0.152 & 0.152 & 0.111 & 0.195 & 0.191 & & & & \\
\hline & $p$ value & 0.597 & 0.273 & 0.273 & 0.360 & 0.191 & & & & \\
\hline \multirow{4}{*}{ Saltiness } & T0 & 5.4 & 5.8 & 5.5 & 5.6 & 5.6 & 0.086 & 0.132 & 0.969 & 0.523 \\
\hline & $\mathrm{T} 8$ & 6.0 & 6.1 & 5.7 & 6.1 & 5.7 & 0.091 & 0.097 & 0.036 & 0.462 \\
\hline & SEM & 0.120 & 0.108 & 0.089 & 0.148 & 0.141 & & & & \\
\hline & $p$ value & 0.012 & 0.133 & 0.048 & 0.318 & 0.141 & & & & \\
\hline \multirow{4}{*}{ Rancidness } & T0 & 2.1 & 2.0 & 1.9 & 2.1 & 2.0 & 0.138 & 0.880 & 0.729 & 0.410 \\
\hline & $\mathrm{T} 8$ & 2.7 & 2.7 & 2.7 & 2.8 & 2.5 & 0.138 & 0.988 & 0.282 & 0.358 \\
\hline & SEM & 0.182 & 0.162 & 0.139 & 0.251 & 0.234 & & & & \\
\hline & $p$ value & 0.099 & 0.041 & 0.010 & 0.014 & 0.234 & & & & \\
\hline
\end{tabular}


Table 5. Cont.

\begin{tabular}{|c|c|c|c|c|c|c|c|c|c|c|}
\hline & & \multicolumn{3}{|c|}{ Commercial Category (1) } & \multicolumn{2}{|c|}{ Packaging (2) } & \multirow{2}{*}{ SEM } & \multicolumn{3}{|c|}{$p$ Value } \\
\hline & & White & Red & Black & MAP & Vacuum & & 1 & 2 & $1 \times 2$ \\
\hline \multirow{4}{*}{ Strange tastes } & T0 & 1.5 & 1.3 & 1.5 & 1.5 & 1.4 & 0.077 & 0.477 & 0.367 & 0.243 \\
\hline & $\mathrm{T} 8$ & 1.9 & 1.7 & 1.7 & 1.8 & 1.7 & 0.099 & 0.665 & 0.685 & 0.140 \\
\hline & SEM & 0.128 & 0.092 & 0.084 & 0.196 & 0.108 & & & & \\
\hline & $p$ value & 0.163 & 0.043 & 0.239 & 0.465 & 0.108 & & & & \\
\hline \multirow{4}{*}{ Persistency } & T0 & 6.0 & 6.0 & 5.9 & 6.0 & 5.9 & 0.097 & 0.899 & 0.887 & 0.158 \\
\hline & $\mathrm{T} 8$ & 6.5 & 6.4 & 6.4 & 6.4 & 6.5 & 0.094 & 0.968 & 0.510 & 0.975 \\
\hline & SEM & 0.123 & 0.112 & 0.096 & 0.198 & 0.148 & & & & \\
\hline & $p$ value & 0.021 & 0.048 & 0.043 & 0.136 & 0.148 & & & & \\
\hline
\end{tabular}

SEM, standard error of mean; Black (100\% Iberian pigs finished in Montanera); Red ( $50 \%$ Iberian $\times$ Duroc pigs finished in Montanera); White $(50 \%$ Iberian $\times$ Duroc pigs reared in a semi-intensive system with commercially feeding). Modified atmosphere packaging (MAP) $\left(70 \% \mathrm{~N}_{2}: 30 \% \mathrm{CO}_{2}\right)$. Vacuum packaging. T0, initial; $\mathrm{T} 8,8$ months of storage.

Only the sensory parameter "intensity of marbling" was significantly affected by the commercial category. Hams in the Black category had lower marbling than those in the White category, while the Red category showed intermediate levels. Marbling is mostly associated with intramuscular fat content, and this parameter shows an important variability. Hams with Black category are expected to have higher marbling since Iberian pigs reared in the Montanera system usually have higher intramuscular fat content than those commercially feeding [41]. These results could also be associated to the generally higher life weight of pigs reared in the Montanera system with respect to the semi-intensive systems [42]. In addition, there is a great variability between the different genetic lines of Iberian pigs [43], which also affects the quality of dry-cured meat products [44], as well as the Duroc line $[34,38]$ used in animals from the Red and White categories.

The intensity of flavour was also affected by the type of packaging and higher scores were found in vacuum packaging than in MAP at T8. In addition, this parameter decreased after eight months of storage in all commercial categories of ham. Iberian dry-cured ham is appreciated for its sensory properties; therefore, it is important to know the long-term evolution of these parameters, especially for the Iberian manufacturing sector and export market [45], as well as by consumers, since this ham is considered by them as a top-quality product. Eight months of storage is a long storage time for Iberian sliced dry-cured ham. The decrease of flavour perceived by panellists would be in line with the recommendations to consume sliced Iberian ham before 6-8 months, not due to microbiological problems, but because the sensory quality of the ham starts to decrease significantly after that time, e.g., the reductions of flavour intensity or the development of undesirable flavours. However, as far as we know, there are no studies on the sensory changes in sliced dry-cured ham stored longer than five months $[26,46]$. Lipid oxidation is the principal route for the formation of volatile aromatic compounds in Iberian dry-cured meat products during maturation; thus, to a certain level, lipid oxidation is positive [40], even though compounds produced during storage from lipid oxidation are considered negligible.

Texture parameters such as hardness and juiciness were not affected by the commercial category or the type of packaging.

Hams packaged in MAP were perceived as saltier than those in vacuum packaging. The results are difficult to explain since saltiness is mostly related to salt content. These changes could be influenced by the higher dehydration of hams in MAP than those in vacuum packaging. In general, salt perception was increased during storage although changes were only significant for the Black and White categories.

The intensity of rancidness perception was not affected by the commercial category or the type of packaging of sliced ham. However, during storage, the slices of Red and White commercial categories and the slices in MAP were perceived significantly more rancid after eight months of storage than at the beginning. Very rancid hams are considered defective. Ruiz, García, Muriel, Andrés and Ventanas [47] reported a certain negative influence of 
rancidity on the acceptability of Iberian ham. The increases of rancidness agree with the increases in TBARS values during storage; however, despite of their higher TBARS values at T12, slices from the Black category were more stable during storage than those from the other categories. In this line, slices of Iberian dry-cured ham from pigs reared outdoors with acorns and grass with high content of antioxidants [30] would be generally more stable since antioxidants are incorporated into muscle [48]. This type of ham could present a better technological aptitude for processes such as slicing, packaging and processing (i.e., high pressure treatment) than those hams from pigs with other rearing systems, as suggested Amaro-Blanco et al. [26] considering sliced Iberian dry-cured shoulder from pigs reared in the Montanera system that were vacuum packaged and treated by high pressure processing. Regarding the type of packaging, Cilla et al. [29] and Parra et al. [10] found that the flavour was better preserved in vacuum rather than MAP, which would agree with the significant increase of rancidness in MAP at T8 compared to T0, while vacuum packaging showed similar scores at both times. Amaro-Blanco et al. [26] found that sensory parameters of sliced Montanera Iberian dry-cured shoulder were not affected after five months of storage.

The perception of strange flavours was increased in all groups during storage, although differences were only significant for slices from the Red category. On the other hand, the persistency of the flavour in the top and bottom of the mouth is a positive attribute for high quality Iberian dry-cured hams. The increase of persistency during storage could be also linked to the increase of lipid oxidation-derived compounds.

The principal component analysis about the different commercial categories of Iberian dry-cured ham at different packaging conditions (Figure 1) revealed some differences in the sample distribution. In vacuum packaging, the discrimination was not as clear (Figure 1A.1) as in MAP, which allowed the separation of individuals according to their commercial category (Figure 1B.1). Thus, the last one showed how samples from White category tended to have positive scores on the principal component (PC) 1 and 2 axes, which could be explained by positive loadings of the variables C16:0, C18:0 and SFA on the PC1 axis. On the contrary, no discrimination was observed among the samples derived from the Red and Black categories, which provided samples located in the mid-zone of the map and even tended to have negative scores on both axes, as explained by the negative loadings of the variables $\alpha$ - and $\gamma$-tocopherol, C18:1 and MUFA (PC1) and C18:2, C18:3 and PUFA (PC2). These results support the stronger influence exerted by the production system-Montanera-compared to the purity breed on the composition of antioxidants and fatty acid profile in Iberian dry-cured hams. Figure 2A.2,B.2 shows the evolution of packages during storage. Vacuum packaging samples stored for 12 months were clearly located on the left of the PC1, which could mainly be explained because of the negative loadings of SFAs on the PC1 axis. MAP samples at 12 months of storage had positive scores on the PC2 axis, which could be due to decrease of PUFA during at the end of the storage time of the study.

When the packaging effect in each commercial category was explored, the projection of the samples onto the space defined by PC1 and PC2 (Figure 2) showed that the model did not discriminate between both packaging types-vacuum and MAP-regardless of the commercial category considered, Black (Figure 2A), Red (Figure 2B) or White (Figure 2C). Henceforth, the relative position of the samples suggests that physico-chemical differences accounting for type of packaging were not enough to allow the discrimination of the three commercial categories under study. The overall effect evaluated through the PCA analysis would confirm the higher influence of the commercial category (which is affected by the rearing system and the genotype) over the packaging conditions (vacuum vs. MAP) on the quality traits of sliced Iberian dry-cured ham.

\section{Conclusions}

Iberian dry-cured ham from different commercial categories, established on the basis of genetic and feeding/production conditions, presented important differences on antioxi- 
dants and fatty acids profile, being tocopherols and monounsaturated fatty acids higher in those from animals reared in the Montanera system. However, these slices did not better maintain the colour than those from pigs commercially fed during long storage times. During storage, the fatty acids profile showed important changes, probably due to the lipolytic reactions, which could be more intense in hams from pigs commercially fed. Despite the initial higher levels of protein and lipid oxidation in dry-cured ham slices from the Black category, they did not develop higher rancidness than those from the other categories.

MAP better preserved the colour and the antioxidants content than vacuum packaging, while vacuum packaging reduced lipid oxidation development and the brightness and flavour of slices. The improvement in the future of these packaging types (i.e., active packaging and packages permeability to oxygen) could increase the shelf life of sliced Iberian dry-cured ham.

Author Contributions: Conceptualization, D.T.; methodology, R.C., A.O.; software, A.O., D.T.; formal analysis, R.C.; investigation, D.T.; resources, D.T.; data curation, R.C.; writing-original draft preparation, R.R.; writing - review and editing, S.G.-T., M.M.L.-P.; project administration, D.T.; funding acquisition, D.T. All authors have read and agreed to the published version of the manuscript.

Funding: The authors acknowledge the financial support by the project IB16182 of Government of Extremadura and FEDER founds and the PhD-student grant of Alberto Ortiz (PD16057).

Data Availability Statement: Data supporting reported results will be available on request.

Acknowledgments: The authors acknowledge the meat quality area from CICYTEX and Señorío de Montanera factory for manufacturing the samples used for this piece of research.

Conflicts of Interest: All authors declare no conflict of interest.

\section{References}

1. Díaz-Caro, C.; García-Torres, S.; Elghannam, A.; Tejerina, D.; Mesias, F.J.; Ortiz, A. Is production system a relevant attribute in consumers' food preferences? The case of Iberian dry-cured ham in Spain. Meat Sci. 2019, 158. [CrossRef] [PubMed]

2. Pugliese, C.; Sirtori, F. Quality of meat and meat products produced from southern European pig breeds. Meat Sci. 2012, 90, 511-518. [CrossRef] [PubMed]

3. Tejerina, D.; García-Torres, S.; Cabeza De Vaca, M.; Vázquez, F.M.; Cava, R. Effect of production system on physical-chemical, antioxidant and fatty acids composition of Longissimus dorsi and Serratus ventralis muscles from Iberian pig. Food Chem. 2012, 133, 293-299. [CrossRef] [PubMed]

4. Ramírez, R.; Cava, R. The crossbreeding of different Duroc lines with the Iberian pig affects colour and oxidative stability of meat during storage. Meat Sci. 2007, 77, 339-347. [CrossRef] [PubMed]

5. Carrapiso, A.I.; Bonilla, F.; García, C. Effect of crossbreeding and rearing system on sensory characteristics of Iberian ham. Meat Sci. 2003, 65, 626-629. [CrossRef]

6. Fuentes, V.; Ventanas, S.; Ventanas, J.; Estévez, M. The genetic background affects composition, oxidative stability and quality traits of Iberian dry-cured hams: Purebred Iberian versus reciprocal Iberian $\times$ Duroc crossbred pigs. Meat Sci. 2014, 96, 737-743. [CrossRef]

7. Ventanas, S.; Ventanas, J.; Tovar, J.; García, C.; Estévez, M. Extensive feeding versus oleic acid and tocopherol enriched mixed diets for the production of Iberian dry-cured hams: Effect on chemical composition, oxidative status and sensory traits. Meat Sci. 2007, 77, 246-256. [CrossRef]

8. RD 4/2014. Real Decreto por el que se Aprueba la Norma de Calidad para la Carne, el Jamón, la Paleta y la Caña de Lomo Ibérico; Spanish Ministry of Agriculture, Fisheris and Food: Madrid, Spain, 2014.

9. Ortiz, A.; Tejerina, D.; Díaz-Caro, C.; Elghannam, A.; García-Torres, S.; Mesías, F.J.; Trujillo, J.; Crespo-Cebada, E. Is packaging affecting consumers' preferences for meat products? A study of modified atmosphere packaging and vacuum packaging in Iberian dry-cured ham. J. Sens. Stud. 2020, 35, e12575. [CrossRef]

10. Parra, V.; Viguera, J.; Sánchez, J.; Peinado, J.; Espárrago, F.; Gutierrez, J.I.; Andrés, A.I. Effect of exposure to light on physicochemical quality attributes of sliced dry-cured Iberian ham under different packaging systems. Meat Sci. 2012, 90, 236-243. [CrossRef]

11. García-Esteban, M.; Ansorena, D.; Astiasarán, I. Comparison of modified atmosphere packaging and vacuum packaging for long period storage of dry-cured ham: Effects on colour, texture and microbiological quality. Meat Sci. 2004, 67, 57-63. [CrossRef]

12. Parra, V.; Viguera, J.; Sánchez, J.; Peinado, J.; Espárrago, F.; Gutierrez, J.I.; Andrés, A.I. Modified atmosphere packaging and vacuum packaging for long period chilled storage of dry-cured Iberian ham. Meat Sci. 2010, 84, 760-768. [CrossRef] [PubMed] 
13. Contador, R.; Ortiz, A.; del Ramírez, M.R.; García-Torres, S.; López-Parra, M.M.; Tejerina, D. Physico-chemical and sensory qualities of Iberian sliced dry-cured loins from various commercial categories and the effects of the type of packaging and refrigeration time. LWT 2021, 141, 110876. [CrossRef]

14. García-Torres, S.; Contador, R.; Ortiz, A.; Ramírez, R.; López-Parra, M.; Tejerina, D. Physico-chemical and sensory characterization of sliced Iberian Chorizo from raw material of three commercial categories and stability during refrigerated storage packaged under vacuum and modified atmospheres. Food Chem. 2021, in press. [CrossRef]

15. AOAC. Official Methods of Analysis of the Association of Official Analytical Chemists, 17th ed.; Association of Analytical: Washington, DC, USA, 2003.

16. AOAC. Official Methods of Analysis, 17th ed.; Association of Official Analytical Chemists: Gaithersburg, MD, USA, 2000.

17. Folch, J.; Lees, M.; Sloane-Stanley, G. A simple method for the isolation and purification of total lipids from animal tissues. J. Biol. Chem. 1957, 193, 265-275.

18. Cayuela, J.; Garrido, M.; Bañón, J.; Ros, J. Simultaneus HPLC Análisis of $\alpha$-tocopherol an cholesterol in fresh pig meat. J. Agric. Food Chem. 2003, 51, 1120-1124. [CrossRef] [PubMed]

19. Salih, A.M.; Smith, D.M.; Price, J.F.; Dawson, L.E. Modified extraction 2-thiobarbituric acid method for measuring lipid oxidation in poultry. Poult. Sci. 1987, 66, 1483-1489. [CrossRef] [PubMed]

20. Oliver, C.N.; Ahn, B.W.; Moerman, E.J.; Goldstein, S.; Satadtman, E.R. Aged-related changes in oxidized proteins. J. Biol. Chem. 1987, 262, 5488-5491. [CrossRef]

21. Andrés, A.I.; Cava, R.; Ventanas, J.; Muriel, E.; Ruiz, J. Lipid oxidative changes throughout the ripening of dry-cured Iberian hams with different salt contents and processing conditions. Food Chem. 2004, 84, 375-381. [CrossRef]

22. Morales, R.; Guerrero, L.; Aguiar, A.P.S.; Guàrdia, M.D.; Gou, P. Factors affecting dry-cured ham consumer acceptability. Meat Sci. 2013, 95, 652-657. [CrossRef]

23. Lindahl, G.; Lundström, K.; Tornberg, E. Contribution of pigment content, myoglobin forms and internal reflectance to the colour of pork loin and ham from pure breed pigs. Meat Sci. 2001, 59, 141-151. [CrossRef]

24. Andersen, H.J.; Bertelsen, G.; Boegh-Soerensen, L.; Shek, C.K.; Skibsted, L.H. Effect of light and packaging conditions on the colour stability of sliced ham. Meat Sci. 1988, 22, 283-292. [CrossRef]

25. Andersen, H.J.; Skibsted, L.H. Kinetics and mechanism of thermal oxidation and photooxidation of nitrosylmyoglobin in aqueous solution. J. Agric. Food Chem. 1992, 40, 1741-1750. [CrossRef]

26. Amaro-Blanco, G.; Delgado-Adámez, J.; Martín, M.J.; Ramírez, R. Active packaging using an olive leaf extract and high pressure processing for the preservation of sliced dry-cured shoulders from Iberian pigs. Innov. Food Sci. Emerg. Technol. 2018, 45, 1-9. [CrossRef]

27. Arnau, J. Principales Problemas Tecnológicos en la Elaboración del Jamón Curado. In El Jamón Curado: Tecnología y Análisis de Consumo: Simposio Especial, 44th ICOMST; Estrategias Alimentarias: Madrid, Spain, 1998; pp. 72-86.

28. Isabel, B.; Cordero, G.; López-Bote, C.; Daza, A. Tocopherol content, weight loss and instrumental color analysis of Iberian dry-cured ham as affected by rearing and feeding systems. Grasas Aceites 2009, 60, 248-254. [CrossRef]

29. Cilla, I.; Martínez, L.; Beltrán, J.A.; Roncalés, P. Dry-cured quality and acceptability as affected by the preservation system used for retail sale. Meat Sci. 2006, 73, 581-589. [CrossRef]

30. Tejerina, D.; García-Torres, S.; Cabeza de Vaca, M.; Vázquez, F.; Cava, R. Acorns (Quercus rotundifolia Lam.) and grass as natural sources of antioxidants and fatty acids in the " montanera" feeding of Iberian pig: Intra- and inter-annual variations. Food Chem. 2011, 124, 997-1004. [CrossRef]

31. Daza, A.; Rey, A.I.; Ruiz, J.; Lopez-Bote, C. Effects of feeding in free-range conditions or in confinement with different dietary MUFA/PUFA ratios and alpha-tocopheryl acetate, on antioxidants accumulation and oxidative stability in iberian pigs. Meat Sci. 2005, 69, 151-163. [CrossRef] [PubMed]

32. Gandemer, G. Lipids in muscle and adipose tissues, changes during processing and sensory properties of meat products. Meat Sci. 2002, 62, 309-321. [CrossRef]

33. Estévez, M.; Ventanas, S.; Heinonen, M.; Puolanne, E. Protein carbonilation and water-holding capacity of pork subjected to frozen storage. Effect of muscle type, premincing, and packaging. J. Agric. Food Chem. 2011, 59, 5435-5443. [CrossRef] [PubMed]

34. Cava, R.; Ladero, L.; González, S.; Carrasco, A.; Ramírez, M.R. Effect of pressure and holding time on colour, protein and lipid oxidation of sliced dry-cured Iberian ham and loin during refrigerated storage. Innov. Food Sci. Emerg. Technol. 2009, $10,76-81$. [CrossRef]

35. Petrón, M.J.; Muriel, E.; Timón, M.L.; Martín, L.; Antequera, T. Fatty acids and triacylglycerols profiles from different types of Iberian dry-cured hams. Meat Sci. 2004, 68, 71-77. [CrossRef]

36. Ramírez, M.R.; Cava, R. Effect of Iberian $\times$ Duroc genotype on composition and sensory properties of dry-cured ham. J. Sci. Food Agric. 2008, 88, 667-675. [CrossRef]

37. Domínguez, R.; Pateiro, M.; Gagaoua, M.; Barba, F.J.; Zhang, W.; Lorenzo, J.M. A comprehensive review on lipid oxidation in meat and meat products. Antioxidants 2019, 8, 429. [CrossRef]

38. Gandemer, G. Dry cured ham quality as related to lipid quality of raw material and lipid changes during processing: A review. Grasas Aceites 2009, 60, 297-307. [CrossRef] 
39. Clariana, M.; Guerrero, L.; Sárraga, C.; Díaz, I.; Valero, Á.; García-Regueiro, J.A. Influence of high pressure application on the nutritional, sensory and microbiological characteristics of sliced skin vacuum packed dry-cured ham. Effects along the storage period. Innov. Food Sci. Emerg. Technol. 2011, 12, 456-465. [CrossRef]

40. Ramírez, M.R.; Cava, R. Effect of Iberian $\times$ Duroc genotype on dry-cured loin quality. Meat Sci. 2007, 76, 333-341. [CrossRef]

41. Ventanas, S.; Tejeda, J.F.; Estévez, M. Chemical composition and oxidative status of tissues from Iberian pigs as affected by diets: Extensive feeding v. oleic acid- and tocopherol-enriched mixed diets. Animal 2008, 2, 621-630. [CrossRef] [PubMed]

42. Tejerina, D.; Garcia-Torres, S. Effect of Production System and Sex on Different Carcass Traits of Iberian Pigs. In Proceedings of the 7th International Symposium on the Mediterranean Pig, Cordoba, Andalusia, 14-16 October 2010; Options Méditerranéennes. CIHEAM: Zaragoza, Spain, 2010; pp. 401-404.

43. Muriel, E.; Ruiz, J.; Ventanas, J.; Petrón, M.J.; Antequera, T. Meat quality characteristics in different lines of Iberian pigs. Meat Sci. 2004, 67, 299-307. [CrossRef] [PubMed]

44. Carrapiso, A.I.; García, C. Effect of the Iberian pig line on dry-cured ham characteristics. Meat Sci. 2008, 80, 529-534. [CrossRef] [PubMed]

45. Ayuso, F. El Envasado de Jamón Curado. In Proceedings of the II World Congress of Dry Cured Ham, Cáceres, Spain, 27-29 March 2003; Universidad de Extremadura: Cáceres, Spain, 2003.

46. Martínez-Onandi, N.; Rivas-Cañedo, A.; Picon, A.; Nuñez, M. Influence of compositional characteristics and high pressure processing on the volatile fraction of Iberian dry-cured ham after prolonged refrigerated storage. Innov. Food Sci. Emerg. Technol. 2018, 49, 127-135. [CrossRef]

47. Ruiz, J.; García, C.; Muriel, E.; Andrés, A.; Ventanas, J. Influence of sensory characteristics on the acceptability of dry-cured ham. Meat Sci. 2002, 61, 347-354. [CrossRef]

48. Cava, R.; Ventanas, J.; Florencio Tejeda, J.; Ruiz, J.; Antequera, T. Effect of free-range rearing and $\alpha$-tocopherol and copper supplementation on fatty acid profiles and susceptibility to lipid oxidation of fresh meat from Iberian pigs. Food Chem. 2000, 68, 51-59. [CrossRef] 